This item was submitted to Loughborough's Research Repository by the author.

Items in Figshare are protected by copyright, with all rights reserved, unless otherwise indicated.

\title{
Political religion in twentieth-century China and its global dimension
}

PLEASE CITE THE PUBLISHED VERSION

PUBLISHER

(c) Brill

VERSION

AM (Accepted Manuscript)

LICENCE

CC BY-NC-ND 4.0

REPOSITORY RECORD

Klein, Thoralf. 2019. "Political Religion in Twentieth-century China and Its Global Dimension". figshare. https://hdl.handle.net/2134/15039. 
This item was submitted to Loughborough's Institutional Repository (https://dspace.lboro.ac.uk/) by the author and is made available under the following Creative Commons Licence conditions.

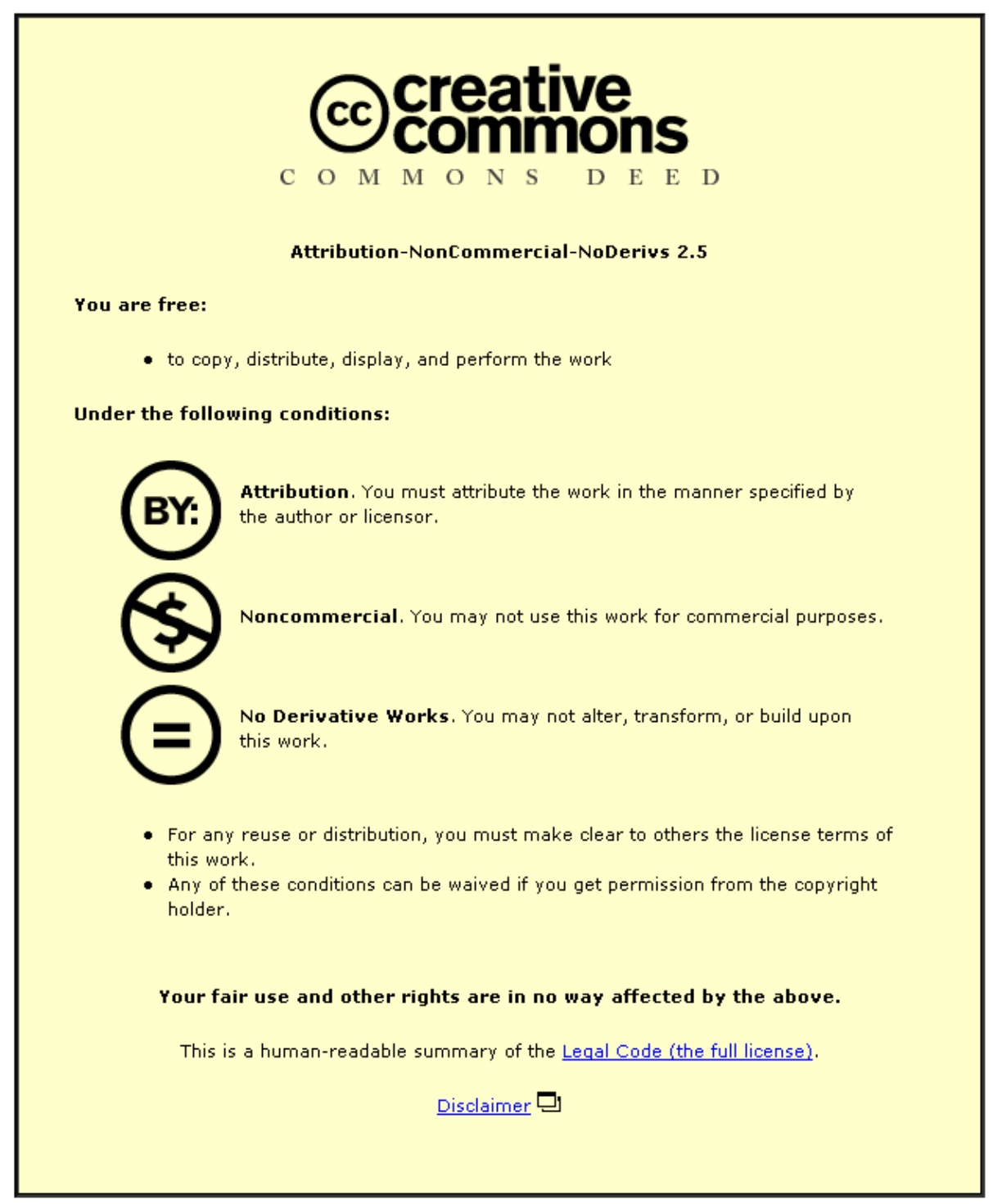

For the full text of this licence, please go to: http://creativecommons.org/licenses/by-nc-nd/2.5/ 


\title{
Political Religion in Twentieth-Century China and Its Global Dimension
}

\author{
Thoralf Klein
}

There are different ways of conceptualizing the relationship between religion and politics in twentieth-century China. One is to examine the religious policies of the state or political organizations. In this case, the political and the religious are treated as more or less autonomous spheres. ${ }^{1}$ Another is to look at the overlap between the two, in particular at the ways that politics became 'religionized.' This approach has evolved into a burgeoning field of research over the past two decades, with studies coming under different labels such as 'political ritual,' 'political (or personality) cult' or 'political religion., ${ }^{2}$ Of these, 'political religion' goes furthest in undermining the binary conceptualization of religion and its 'other' as diametrically opposed categories. ${ }^{3}$ If the process of modern state-building, in China as elsewhere, is to be linked to processes of secularization, ${ }^{4}$ then what constitutes the secular needs to be complicated. For some of the modern political ideologies that emerged in early twentieth-century China not only underpinned state expansion, but impinged on the creation of what Vincent Goossaert and David Palmer have recently referred to as "a self-consciously 'religious' field," which they argue was to a considerable extent a political project. ${ }^{5}$ While it makes sense to conceptualize the emerging forms of mass politics, authoritarianism and totalitarianism as new "affective regimes" For it glosses over the stunning parallels between totalizing ideologies and religion, notwithstanding the fact that the former — in an irony of dialectics — were often adamantly anti-religious. ${ }^{7}$ The concept of political religion can help clarify how the modernizing state as well as modern political organizations not only impacted on the religious field, but how their prescriptive ideologies also became part of that field and must therefore be studied as religious phenomena in their own right.

This is not to say that political religion is the same thing as religion proper. Indeed, this is a matter of debate amongst proponents of the concept, with some scholars using the religious

1 See, for example, Ashiwa and Wank (2009), Poon (2011), Yang (2008), Wang Xiaoming (2003), Zha Shijie (1993), Cohen (1992), Duara (1991), Luo Zhufeng (1991).

2 E. g. Aijmer (1996), Leese (2011), Apter (2005), Mitter (2008).

3 Cf. Asad (2003), p. 22, and Knecht and Feuchter (2008), pp. 14-16.

4 Cf. Yang (2008), pp. 6-7.

5 Goossaert and Palmer (2011), pp. 10-11. Note how this is a marked departure from Bourdieu, who conceives of the political and religious fields as relatively autonomous to one another. Cf. Bourdieu $(1971,2009)$.

6 I borrow this term from Nedostup (2009), pp. 227-28.

7 See Ryklin (2008), esp. pp. 31-33; Riegel (2008), pp. 62-63. 
terminology only metaphorically or by way of analogy, while others argue that political ideologies constitute a new form of religiosity based on modern manifestations of the sacred. ${ }^{8}$ The German-born political scientist Eric Voegelin (1901-1985), one of the founding fathers of the concept, holds that the state is not simply a secular institution and that some of its features must be defined as religious. Tracing the development of political religion from antiquity to Communism and Fascism in the 1930s, Voegelin regards modern political religions as strictly inner-worldly, which distinguishes them from at the 'trans-worldly' redemptive religions (though not necessarily from non-redemptive religions). Political religions are thus at the same time a product of secularization and an attempt to overcome it. ${ }^{9}$ Following the dissolution of the Christian ecclesia, they seek to create a perfect inner-worldly community by offering a renewal that Voegelin calls "apocalyptic," by which term he refers to a perceived need to overcome the forces of evil (be they the bourgeoisie, supposedly inferior races or others) as a prerequisite to attaining social redemption. ${ }^{10}$

This apocalyptic dimension is equivalent to what students of Fascism have called 'palingenesis': the notion of a (national) rebirth from a state of crisis, which derives from Christian soteriology, but can likewise be applied to matters secular. ${ }^{11}$ It is important to note, however, that this utopian dimension of political religion, which promises the creation of an idealized community through an epic struggle, is not incompatible with claims to scientific rationality. In fact, as Voegelin has argued, such modern "apocalyptic revelations" often pretend to be scientific, while in his view they are in fact "myths" relying on the emotional mobilization of the masses. ${ }^{12}$ Such mobilization is achieved through the focus on a political leader, who takes the place of the godhead, through the persuasive deployment of rituals and symbols, through expressions of faith in the leader and his teaching and finally through the dissemination of a new revolutionary morality that includes selfexamination and, if necessary, self-sacrifice. ${ }^{13}$

It is obvious that while some of the above elements were not unknown in pre-modern China, others-in particular a faith-based rhetoric and a Christianity-based soteriological concept—were

8 For the former cf. Aron (1957) and the otherwise useful chapter by Riegel (1999); for the latter Gentile (2006).

9 Voegelin (2008), pp. 24-33.

10 Ibid., pp. 50-52 and 59-61.

11 Griffin (1991), pp. 32-36; cf. also Passmore (2002), p. 20.

12 Voegelin (2008), pp. 61-63. Cf., however Mitter (2008), who argues that Maoism (and by implication the Guomindang, which preceded it) cannot be classified as a political religion because unlike Fascism and the Japanese right in the Shōwa period, it did not seek to overcome reason. This is to gloss over the undoubtedly irrational dimension of Communism (not only in its Chinese form) and would leave right-wing movements as the only political religions.

13 Voegelin (2008), pp. 64-69; for the moral and ascetic dimension see also Goossaert and Palmer (2011), p. 169. 
unfamiliar in a country where the focus traditionally was not on believing, but on 'doing' religion. ${ }^{14}$ Political religion in China is thus not only a modern concept, it is also bound up with processes of globalization.

In this essay, I shall examine the global dimension of political religions in China, applying a longitudinal section through the twentieth century. I will embed the phases that can be most easily identified as having been politically religious - the rule of the National Party or Guomindang 國民黨 (GMD, 1925-1949) and that of the Chinese Communist Party (CCP) under the leadership of Mao Zedong 毛澤東 (1941-1976)—within the broader intellectual and political trends as well as their global connotations. My argument is that firstly, the emergence of political religion in China can be interpreted as a constitutive element of a double globalizing process: directly through Moscow's strategy of Communist world revolution and both directly and indirectly through the global spread of Christianity - it must be borne in mind that the Soviet sacralization of the political, as exemplified in the cult of Lenin, owed a great deal to the Christian religion. ${ }^{15}$ Despite being an emulation of Soviet beliefs and practices, the cult of Sun Yatsen (usually referred to in Chinese as Sun Zhongshan 孫中山 , 1866-1925), my first major case study, was part of a global wave of totalitarian movements and regimes sharing features of political religion. But secondly, this was not a one-way process. As my second case study shows, China's ideological and political leader Mao Zedong (1893-1976) became an icon outside China in the 1960s and early 1970s, contributing to the emergence of a 'global moment' by inspiring student protests in Europe as much as revolutionary insurgents across the Third World. ${ }^{16}$ Finally, although it would appear that forms of political religion were off the CCP's agenda following Mao's death, I show that vestiges of political religion emerged in new contexts, providing guidance in a rapidly shifting, fluid and realigning world.

\section{Global Factors in the Emergence of Political Religion in China}

The socio-political transformation of China at the turn of the twentieth century conformed to a long-term global trend identified by the sociologist Reinhard Bendix (1916-1991) in the late 1970s: the transition from monarchical rule legitimized by religious sanction to forms of political authority held in the name of the people. ${ }^{17}$ Such authority does not have to be democratic; what is important is that "unless measures are taken to prevent it, rulers and ruled alike must advance their claims in

14 See Chau (2011).

15 See Ryklin (2008).

16 For the term 'global moment' see Conrad and Sachsenmaier (2007), pp. 12-16.

17 Bendix (1980), pp. 4-10. Note that the word 'global' is not part of Bendix's vocabulary (a search engine yields only one hit), but he uses the roughly equivalent term 'universal' repeatedly throughout the volume. 
public and hence with an eye to public reactions that are likely to follow." ${ }^{18}$ In China, the gradual shift towards constitutional monarchy after 1901 and, more importantly, the abrupt demise of the Qing dynasty in 1911/12 left a vacuum that was waiting to be filled with new concepts able to achieve domestic stability and international equality for a country still attempting to extricate itself from the fetters of imperialism.

As a result, the connection between religion and politics that had been the bedrock of late Imperial China underwent a major shift. Up until the late nineteenth century, the emperor was the head and high priest of state religion, with officials on each rung of the bureaucratic ladder acting as lesser priests by making regular sacrifices to specific deities. ${ }^{19}$ Although its purpose was the maintenance of order and stability in the empire, it clearly involved a transcendent dimension that consisted in what the anthropologist Jordan Paper, pointing to a common theme underlying the generally pluralistic and heterogeneous religious landscape in China, has identified as the ritual core of Chinese religion(s): the exchange of sacrifices for protection. ${ }^{20}$ Hence it can be classified as innerworldly, but not as redemptive. When the Qing dynasty embarked on a constitutional programme in the last decade of its rule, it attempted to back this up by elevating the sacrifices for Confucius, who was to become the centrepiece of a dynastic patriotism. What is important here is not so much that this attempt at rallying the population behind the dynasty fell short of its objective. Rather, it is that although the elevation of the great sage marked a rupture with the established order of state religion, geared towards the emerging concepts of nationalism and citizenship, ${ }^{21}$ it derived from a timehonoured precedent and did not focus - as political religions would later do - on a contemporary leader.

However, the same global intellectual, cultural and social currents that the Qing dynasty sought to address through innovative forms of worship, pulled China into a different direction altogether. Modern politico-scientific concepts such as (social) Darwinism, liberalism, nationalism and communism began to be received by China's emerging intelligentsia through the translations of Yan $\mathrm{Fu}$ 嚴復 (1853-1921) and others. ${ }^{22}$ This was part of a wider transformation: the creation of a modern political, social and scientific language, based first on missionary translations and since about 1895 - the year of Qing China's crushing defeat at the hands of Japan--on the indirect adoption of

18 Ibid., p. 8.

19 Feuchtwang (1978), especially pp. 106-07. For the sake of simplicity, I will not engage here in a discussion about the term 'religion' in China, nor about the concern for orthodoxy and the religious policy of the Ming and Qing dynasties.

20 Paper (1995), pp. 26, 47. For the concept of religious landscape and its plurality, see Goossaert and Palmer (2011).

21 See Kuo Ya-pei (2008); Harrison (2001), pp. 90-94.

22 Schwartz 1964. 
modern terms by way of Japanese translations of 'Western' texts. ${ }^{23}$ The first years of the twentieth century also saw a new rhetoric of nationalism emerge, centred around terms such as the 'partition' (guafen 瓜分) of China, its 'existence or downfall' (cunwang 存亡), the necessity to 'save the nation' (jiuguo 救國), the vilification of all who betrayed or, literally, 'sold the country' (maiguo 賣國) and finally, the idea of 'national humiliation' (guochi 國恥) as a powerful metaphor for China's domination by 'Western' imperialism. ${ }^{24}$ This was accompanied by a discourse on martyrdom as well as an evolving culture of largely non-violent protest that for the first time manifested itself on a large scale during the anti-American protests of 1905. The latter included the occupation (or indeed the creation) of symbolic spaces, demonstrations, boycotts, public telegrams and other forms of agitation. ${ }^{25}$ As in other colonies and semi-colonies across the globe, nationalism became a powerful instrument for resisting the imperialists and claiming and asserting independence.

Accordingly, the nation was the first inner-worldly political object to become sacralized. Early nationalism also revealed the apocalyptical dimension of a secular ideology for the first time in Chinese politics, as the existence of the Chinese nation had to be defended not only against imperialism, but also against the Manchu Qing 清 dynasty. For example, in his Wangguo pian 亡國篇 (Essay on the downfall of the nation), published in 1904/05, Chen Duxiu 陳獨秀 (1879-1942) juxtaposes the traditional change of an Imperial dynasty to the downfall of the Chinese nation-state. According to him, China "already counts as a perishing country in the world" because its territory, economic rights and sovereignty had been seized by foreigners. ${ }^{26}$ For Chen, territory in particular is "the first important thing for a state... Today, no nation-state in the world, can cede an inch of its sacred and inviolable territory to other people." 27

With its borrowing of religious language, its rhetoric of apocalypse and palingenesis and its culture of practical activism, early Chinese nationalism bears some similarities to later, full-fledged forms of political religion. Where it differs - and what disqualifies it as a political religion in the strict sense of the term--is its lack of focus of worship, organizational structure and clearly articulated faith. From the late Qing through the early Republic, nationalism was ideologically heterogeneous and structurally dispersed, despite the impressive mass demonstrations between 1905 and the mid-1920s

23 For this shift see Elman (2005), especially p. 395; for the wider context also the contributions in Lackner and Vittinghoff (2004).

24 Rankin (2002), p. 339; Cohen (2003).

25 See, among others, Rankin (2002), pp. 335-38; Lee (2009); Zhou Yongming (2006), Gerth (1998).

26 Chen Duxiu (n.d.), ch. 1. The original text appeared in various instalments in the periodical Anhui suhua bao 安徽俗話報.

27 Ibid., ch. 2. 
that featured students as their organizational backbone. ${ }^{28}$ Such bottom-up approaches were balanced by successive Republican governments' attempts to create a modern citizenry conforming to arguably global but definitely 'Western'-inspired cultural standards. The political leadership introduced political symbols such as the five-colour flag or the Gregorian calendar (and with it national holidays) and propagated 'civilized' forms of clothing and etiquette. ${ }^{29}$ But these too fell short of creating a unified political faith or organization.

By the late 1910s, it had become clear that China was still being denied its rightful place in the world-wide system of nation-states. What made the Chinese public painfully aware of this was not only the fragmentation of the Republican polity into fiefdoms controlled by warlords. It was also the disappointing outcome of what Erez Manela has called the 'Wilsonian moment,' a global conjunction in which China played no small part. ${ }^{30}$ Educated Chinese had been enthused by US president Woodrow Wilson's (1856-1924) famous Fourteen Points, proclaimed in January 1918 because they seemed to usher in an era of national self-determination that would put an end to imperialism in China. Although it is by no means certain that Wilson knowingly let China down, ${ }^{31}$ the Paris Peace Conference in 1919 not only failed to respond to China's attempt at a total liquidation of imperialist privileges, it also awarded the former German colony of Kiaochow (Jiaozhou 膠州) to Japan. Chinese protests against this diplomatic failure of their political representatives merged with an ongoing project of cultural rejuvenation to form the May Fourth movement of 1919.

It is impossible to go into detail here; what is important is that both the negative results of the global Wilsonian moment and the Chinese nationalist response to it were catalysts in the development of political religion in China. The former enabled alliances between governments viewing themselves as 'losers' of the peace process. The May Fourth movement, on the other hand, marked the watershed between more liberal visions of the nation-state and society and a new era of mass politics in China that was dominated by monopolistic parties. Although the intellectual leaders of the movement extolled scientific rationalities, their youthful followers were also driven by a Romanticist sense of the ego. ${ }^{32}$ It was at this decisive moment (and crisis of the new political system), and in the wake of the National Revolution of the mid-1920s, that China's interactions with the wider world spawned fullfledged political religions.

\section{The Guomindang and the Cult of Sun Yatsen}

28 Zarrow (2005), p. 122.

29 Harrison (2000), pp. 49-92; Zarrow (2012), pp. 216-21.

30 See Manela (2007).

31 See Elleman (2002).

32 See Mitter (2004), pp. 120-23. 
The National Party or Guomindang (GMD) was the first political organization to institute a comprehensive political religion in China. In this process, the alliance between the Nationalist leader Sun Yatsen and the Soviet Union served as the catalyst that transformed the Nationalists "from a collection of followers of a national hero to a highly organized party of disciplined individuals, united by the acceptance of a common revolutionary program.. ${ }^{33}$ This sea change in organization outlasted the GMD's Soviet connection and the simultaneous united front with the Chinese Communist Party (CCP) after both eventually broke up in 1927.

From the Bolshevik perspective, the alliance with the GMD, then based in Canton (Guangzhou 廣州) in South China, was part of a strategy of world revolution, although the Soviet government simultaneously pursued an interest-driven policy of bilateral negotiations with the feeble central government in Beijing. In order to reach out to revolutionary organizations in other countries, the Bolsheviks had founded the Communist International (Comintern) in 1919 as its global revolutionary arm. The Comintern was tightly controlled by the Politburo of the Russian (since 1922: Soviet) Communist Party, and its representatives in China cooperated closely with Soviet diplomats. After the hopes for a success of Communist revolutions in Western Europe had foundered, the strategy of the Comintern consisted in supporting national-revolutionary movements at the colonial and semi-colonial periphery and especially in the 'East' as a means of undermining imperialism (defined as the highest stage of capitalism by Lenin), building up a 'reserve' for world revolution and winning 'natural' allies for revolutionary Russia. Although nationalist liberation movements were mostly classified as bourgeois-democratic, the Soviet leader Vladimir Ilyich Lenin (1870-1924) and others initially toyed with the idea that 'Eastern' countries might directly advance to socialism, bypassing the capitalist stage. ${ }^{34}$

The alliance between the GMD and the Soviet Union/Comintern was not free of tensions, as Sun Yatsen insisted on putting the National Party on an independent footing. Nevertheless, the Comintern representatives in China made fundamental contributions to the reconstruction of the party: They made Sun and the GMD aware of the value of centralized propaganda work. ${ }^{35}$ They reorganized the party into a hierarchical apparatus based on the principle of democratic centralism. They created a new type of army that was under party control, heavily ideologized and active in propaganda work. ${ }^{36}$ And in so doing, they provided the context for Sun's reformulating his ideology, the Three People's Principles (Sanminzhuyi 三民主義), in a series of lectures which for all their lack of coherence were his most systematic attempt at creating a political platform. These reflected themselves a mixture of

33 Leng and Palmer (1976), p. 76.

34 Kuo Heng-yü et al. (1996), pp. 27-52; Pantsov (2002), pp. 33-36; Riegel (1999), pp. 335-36. For the Soviet Union's bilateral China policy cf. Elleman (1997).

35 Bastid-Bruguière (2002), pp. 17-23.

36 Li Yuzhen (1996), pp. 267-88; Bergère (1994), pp. 384-94. 
global influences reaching from Soviet und liberal American as well as Christian writings to observations on empires and colonies. ${ }^{37}$ In the opening passage of his first lecture, Sun defined his ideology as follows: "Using the simplest definition, we can say that the Three People's Principles are the principles of saving the nation-state. What is a principle? A principle is an idea, a belief (xinyang 信仰) and a force. ${ }^{38}$ Sun thus emphasized the apocalyptic character of the national revolution; at the same, this passage is indicative of how a religious vocabulary found its way into the political language of China. ${ }^{39}$ In the following years it began to permeate the GMD texts; for example, the Three People's Principles are occasionally referred to as a "Gospel” (fuyin 福音) in which people "believed" (xin 信), the latter term being ubiquitous; party members and adherents of the Nationalists called themselves “adherents” or “disciples” (xintu 信徒, an explicitly Christian term) of Sun's doctrine. ${ }^{40}$

The National Revolution of 1925-1928 which gave the Guomindang nominal control over (almost) the entire Chinese territory, a mixture of military campaigns and the largest mass movement China had seen to date, bore out this pattern. Public agitation was directed at warlords and foreign imperialists (including Christian missionaries); the latter were not only vilified, but sometimes demonized outright, although the GMD leadership and its Soviet allies may have sought to curb excesses so as not to precipitate a conflict with the Western powers. ${ }^{41}$ Sun Yat-sen's untimely death in March 1925 prevented him to witness this; even as the National Revolution was still ongoing, the GMD began to use his ritualized memory as the focal point that would enhance the legitimacy of the new regime.

There is no indication that the Comintern advisers directly influenced the emergence of the personality cult around Sun, although the Soviet Union contributed to it by calling its newly established training institute for GMD and CCP cadres in Moscow Sun Yatsen University. Between 1925 and 1928 (two years before it was eventually closed), the University produced around 600 graduates, with both parties accounting for roughly half of them each. ${ }^{42}$ In all probability, however, the construction of Sun Yatsen as a symbol of the new regime began as an attempt by the GMD to tap into spontaneous commemorative activities springing up locally in the wake of the leader's death. Such activities probably drew on Sun's positive image with the Chinese public; he had been respected

37 For a more detailed analysis, see Wells (2001); Bergère (1994), pp. 400-50.

38 Sun Zhongshan (2000), p. 1.

39 See Nedostup (2007), p. 29.

40 A random sample of texts includes Wu Keji 吳克繼 to National Goverment, 26 January 1926, ZDELD 19, Guangzhou Guomin Zhengfu 廣州國民政府, no. 417; “Guangzhou tebieshi dongbu ershiqi nian eryue zhi ershiba nian siyue gongzuo baogao 廣州特別市黨部二十七年二月至二十八年四月工作報告, ” ZDELD 11-2, 1029; “Zongli danchen jinian biaoyu” (1928), p. 55. Cf. already Nedostup (2007), p. 29.

41 Klein (2014), pp. 139-44; Murdock (2006), pp. 165-71.

42 Riegel (1999), pp. 339-40; Sheng Yueh (1971), p. 41. 
as one of very few incorrupt politicians. ${ }^{43}$ Before long, however, the GMD took control and established a host of activities, some of them one-off events, others permanent and some regular: A lavish memorial service for Sun was held after his death. Four years later, his remains were transported in state and with large crowds turning up along the railway tracks from Beijing to his chosen resting place at Nanjing 南京. There, his remains were transferred in solemn procession to a grandiose mausoleum at Purple Mountain (Zijinshan 紫金山), which was reminiscent both of the Hongwu 洪武 Emperor of the Ming 明 Dynasty (ruled 1368-1398), whose tomb is nearby, and—in conscious emulation-of Lenin. ${ }^{44}$ In Guangzhou, a large memorial hall was erected in commemoration of Sun; all over China, streets and urban districts, parks, schools and academic institutions, were named after him, as was his birthplace, the district and town of Xiangshan 香山, which now became Zhongshan 中山. In 1927 and 1930 respectively, the anniversaries of Sun's birth and death joined the calendar of Nationalist holidays, while two other important holidays -10 October as the anniversary of the 1911 revolution and Gregorian New Year as the founding date of the Republic - largely centred on Sun's image as well as his ideology. That dates prior to 1912 were converted from the old lunisolar calendar to the Gregorian one indicates that the commemoration of Sun was bound up with the GMD's attempts at making China part of global modernity. ${ }^{45}$ Finally, honorific titles were bestowed on Sun. In the years following his death, he was referred to as the zongli 總理 or Premier--a title he had assumed in 1924 and which also refers to heads of government—until in 1940, he was canonized as the 'Father of the Nation' (guofu 國父). ${ }^{46}$

Amongst these varied activities, the Weekly Remembrance of the Party held a special place, partly because of its weekly rhythm and partly owing to the concentration of symbols. It was to be held every Monday morning in all party branches, government offices, army units, schools and universities. It was thus not a mass ritual, despite being transmitted to a wider public by intensive press coverage, radio broadcasts and through 'enlarged' (kuoda 擴大) ceremonies directed at mass audiences of several thousand people. ${ }^{47}$ The ritual came in a number of simple steps: ${ }^{48}$ At the beginning, the assembly would rise (or stand, if there were no seats available) in a respectful attitude. The second step, formally introduced in 1933 but informally practiced since 1929, was the singing of

43 Chen Yunqian (2005), pp. 64-65; for Sun's public image see Schiffrin (1980), p. 216.

44 Harrison (2000), pp. 133-44 and 207-30; Wang Liping (1996); Musgrove (2007).

45 Chen Yunqian (2009), pp. 325-410; Poon (2011), pp. 94-97; Nedostup (2007), pp. 44-48. For the global spread of the Gregorian calendar see Macey (2010), p. 34.

46 Bergère (1994), p. 470.

47 Chen Yunqian (2005), pp. 69-70.

48 “Jinianzhou tiaoli" (1926), pp. 1-2. For a revised version cf. Zhonghua Minguo fagui daquan (1936), p. 5721. 
the party anthem (on a text by Sun himself), which in 1943 became the national anthem of the Republic of China (and is still in use on Taiwan today). ${ }^{49}$ Next, participants made three bows facing the image of Sun Yat-sen (and since 1937 to the party and national flags). ${ }^{50}$ This would be followed by a reading of Sun's Last Will and Testament, a text actually drafted on Sun's deathbed by his longtime associate Wang Jingwei 汪精衛 (1883-1944). Next, participants would again face Sun’s image and observe three minutes of silence, followed by a political report, which in 1930 was changed to a lecture on Sun's teaching or a work report. After that, the ceremony would be officially concluded.

Each element of the ritual was fraught with meaning. The reading of Sun's testament contained an apocalyptic dimension, as Sun declared that the revolution had not yet been completed and exhorted his comrades (tongzhi 同志) to let them be guided by his writings and continue to strive for (ultimate) victory. It also addressed China's role in the world in defining as Sun's political objective the liberty and international equality of the Republic; to attain this objective, his followers would have to "unite with the peoples of the world that treat us on an equal footing, so as to pursue the common fight. ${ }^{, 51}$ By the same token, the bow (jugong 鞠躬) was one of those newly introduced practices by which the Republic had sought to mark China's entry into the civilized 'family of nations' from 1912 onwards. For this reason, Republican governments had also propagated its use in religious ceremonies-as a replacement for the abolished kneeling worship. ${ }^{52}$ Finally, the party anthem and flag, both of which in turn became national symbols, replaced older markers by which China had symbolized its national sovereignty and thus claimed its rightful place within the system of nation-states. ${ }^{53}$

Apart from national unification, the Weekly Remembrance also aimed at individual transformation by instilling in each participant a revolutionary work ethic. In the words of one of the Nationalists' leading military figures, General He Yingqin 何應欽 (1890-1987), “we should examine in detail the work we did ourselves in the last week, whether or not we worked hard for the party; ... we ought to scrutinize ourselves, whether or not we fulfilled the mission the Party Leader gave us" and "we party members must examine ourselves whether or not we are already true revolutionary soldiers, whether or not we truly are hard-working party members. ${ }^{, 54}$ Revolution was thus defined as

49 Standing Committee of the Central Executive Committee (CEC) of the GMD, Resolution (68th meeting), n.d., GMD, Huiyi jilu 會議紀錄, 4.3-87.27; “Ge ji dangbu lianchang dangge zhixing banfa 各及黨部練唱黨 歌執行辦法.” Zhonghua Minguo fagui daquan (1936), p. 5721.

50 For the change cf. "Xiuzheng zongli jinianzhou" (1937), Art. 4.

51 Quoted here from Schoppa (2003), p. 69. For the drafting of the document see Bergère (1994), p. 463.

52 See Harrison (2000), pp. 49-85; Chen Yunqian (2005), p. 67.

53 Zarrow (2012), pp. 224-28; Harrison (2000), pp. 98-105 and 192-96; Pi Houfeng (1995).

54 "Bangbu di-yi jinianzhou zhong He zong zhihui zhi baogao," unidentified newspaper clipping, 16 November 
labour, aiming at constructing a modern China that would become part of global modernity. GMD representatives also claimed that this work ethic was what fundamentally distinguished the Weekly Remembrance from Christian beliefs and practices. ${ }^{55}$ However, both the adoption of the weekly rhythm and the introduction of a fixed liturgy composed of body movements, common recitation, song and an exhortatory speech suggest that Christianity was a globalizing influence that both directly and indirectly shaped this political ritual. One of the few authors who openly acknowledged this was a young party official named Wu Xize 吳錫澤 (*1915), who in a 1942 pamphlet noted the formal parallels between Christian service and the Weekly Remembrance and drew the following conclusion:

Our country has always lacked a common religion like Western Christianity that could accommodate the hearts of men and be a place of hope for the spirit of our people. [...] Now the Three People's Principles have already become the central thought practiced by the entire people and all parties and factions. Hence we really shouldn't hinder the Three People's Principles replacing religion. Of course, the Three People's Principles are a scientific doctrine, they are different from the doctrines of religion. But our believing in the Three People's Principles needs precisely the spirit of religious belief; what is called religionization of belief, what is called the thought of the Three People's Principles replacing religion means just that. ${ }^{56}$

To what extent the cult of Sun Yatsen was able to penetrate and transform society is a matter of debate. The Weekly Remembrance, whose target group could be expected to have been loyal followers, gave grounds for many complaints. In particular, commentators bemoaned that despite the penalties with which absentees were threatened, attendance at the ritual was still poor. It seems, however, that violations were not systematically penalized. ${ }^{57}$ On the other hand, after the GMD had regrouped on Taiwan in 1949 it continued to practice the Weekly Remembrance as an attempt at its largely successful political consolidation. ${ }^{58}$

In a global perspective, the Weekly Remembrance and other elements of the GMD's political religion were the result of a global revolutionary project and an ensuing cultural transfer. The GMD no doubt was aware that the Chinese National Revolution was connected with revolutions elsewhere in the world. ${ }^{59}$ Clearly it was not a latecomer-both Soviet Communism and Italian Fascism (another likely model) were newly established regimes like that of the Nationalists. Moreover, the political

1927, GMD, Huiyi jilu, Zongli jinianzhou 總理紀念週 15 November-16 December 1927.

55 Ibid.; cf. also Anon. 1927, p. 7. For a more differentiated evaluation of Christianity cf. Wu Xize (1942), p. 3.

56 Wu Xize (1942), pp. 3-4.

57 Anon. (1927), p. 7; Lin Sen 林森 to Kong Xiangxi 孔祥熙, July 1939, AH, Xingzhengyuan 行政院, 068004.

58 See, for example, Gu Weijun (1989), p. 238.

59 Zhongguo Guomindang Zhejiang Sheng Dangwu Zhidao Weiyuanhui Xunlianbu (1929), pp. 23-24. 
system created by the Guomindang developed roughly simultaneously or even prior to other quasireligious political movements with which it shared a number of features: Kemalism in Turkey ${ }^{60}$ and German National Socialism - the latter, along with Mussolini's Fascism, would inspire the Chinese leader Chiang Kai-shek (Jiang Jieshi 蔣介石, 1887-1975) in the 1930s. Hence, the development of the Sun Yatsen cult and other features of the regime should be seen as constitutive elements of a global process rather than a unidirectional cultural import.

\section{The Mao Cult as a Global Moment, 1960s and 1970s}

Like its predecessor, the Sun Yat-sen cult, the personality cult of Mao Zedong had its roots in Soviet influence in the 1920s and parallels that of Lenin (and, in Mao's case, even more that of Stalin). Neither of the two remained completely faithful to the original blueprint; both made a unique contribution tailored to the conditions of Chinese society. However, whereas the Sun Yat-sen cult had few if any repercussions outside China, that of Mao found an echo across the world, creating something of a global moment in the 1960s and 1970s.

The cult of Mao owed its emergence to a number of factors. Most fundamental of these was the transformation of the CCP from a liberal discussion circle in the May Fourth tradition into the tightly-knit, highly disciplined and thoroughly hierarchical organization it had become by the late 1920s. ${ }^{61}$ As a consequence, the general line issued by the Party Central became sacrosanct: to oppose it was no longer simply an expression of dissent-it amounted to heresy. Political and military developments each played their role in enabling Mao's rise to unquestioned leadership of the CCP, which took the better part of the decade between 1935 and 1945. Although some indications of the subsequent Mao cult appear as early as the late 1930s, the Rectification Movement of 1942 to 1944 seems to have constituted a watershed in promoting Mao as a original and systematic Communist thinker in his own right and in making him the focus of political rituals. The first reference to Mao's writings as a systematic body worthy of the name of 'Thought of Comrade Mao Zedong' (Mao Zedong tongzhi de sixiang 毛澤東同志的思想) dates from February 1941. About a year later, on 8 February 1942, more than 1,000 people at the Communist headquarters in Yan'an celebrated 'Zedong day,' listening to biographical sketches of the party leader. ${ }^{62}$ During the Rectification Movement, party members for the first time studied Mao's writings as "revelatory and 'revealing' texts" that "created 'discourse communities with a transformational sense of their own difference,

\footnotetext{
60 For Kemalism see Kreiser (2011), in particular pp. 219-84.

61 For this process see van de Ven (1991), in particular p. 230-33.

62 Gao Hua (2000), pp. 606-07; cf. Leese (2010), pp. 224-25.
} 
messianic..."63 The anthem 'The East is Red,' whose lyrics were set to a folk song around the time of Mao's ascension to chairmanship of the party in 1945, already features much of the imagery surrounding Mao in later years. ${ }^{64}$ Mao is hailed as a "great saviour" (da jiuxing 大救星, literally “saving star") and "pathfinder" (dailuren 帶路人) who loves the people; the sun, which would become one of the most frequently used tropes for Mao, is present as a symbol for both the man and the party.

It is impossible here to trace in more detail the development of the Mao cult through the 1950s and 1960s, nor to discuss the contributions of other party leaders and practices such as selfcriticism to the creation of a political religion by the Chinese Communists. By the same token, I am less interested in the ways the worship of Mao became a stand-in for religious practices associated with deities, eventually transforming the chairman - like Sun Yatsen before him-into a god of the folk-religious pantheon. ${ }^{65}$ Suffice it to say that the Mao cult was predicated on the notion of the transformative power of belief, both at the individual and social levels. During the Cultural Revolution in particular, propaganda emphasized the closeness of Chairman Mao, allowing him to penetrate into individuals' thinking to a degree unknown for any previous political leader. As a wellknown song stated:

The sun is reddest, / Chairman Mao is closest.

Your brilliant thought / Will forever illuminate my [or: our] heart.

The spring wind is warmest, / Chairman Mao is closest.

Your revolutionary Party line / Will forever guide [my/our] journey.

Your achievements are higher than the sky.

Your loving kindness is deeper than the sea.

The sun in my heart will never set.

Your heart will forever be close to ours. ${ }^{66}$

63 Apter (1995), p. 195.

64 See Hung Chang-tai (1996), p. 920.

65 Landsberger (2002), pp. 153-59 and 161-64; Chao (1999); for the deification of Sun Yatsen cf. Nedostup (2009), p. 274.

66 “Mao zhuxi zui qin 毛主席最亲 [Chairman Mao is closest],” http://baike.baidu.com/view/4096964.htm. 


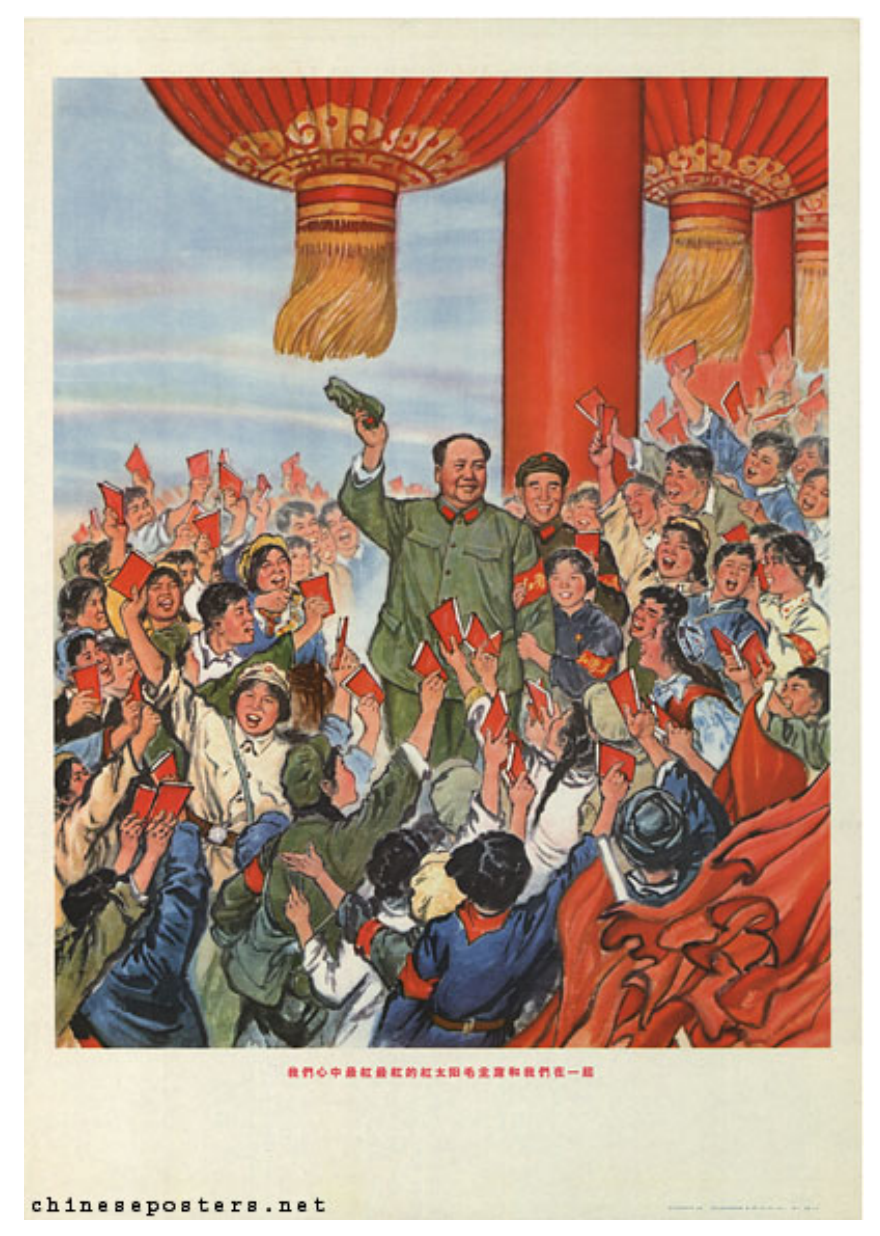

Figure 1. Women xinzhong zuihong zuihongde hong taiyang Mao zhuxi he women xin lian xin 我们心中最红最 红的红太阳毛主席和我们心连心 [The reddest reddest red sun in our heart, Chairman Mao and us heart to heart], propaganda poster by Zhejiang Sheng Gongnongbing Meishu Chuangzuozu 浙江省工农兵美术创作组, January 1968, International Institute of Social History (Amsterdam), IISH collection, BG E3/712.

During the Cultural Revolution, innumerable propaganda posters hammered the same point home (see, for example, fig. 1). The youthful Red Guards, who were the targets of this propaganda, responded with rituals of their own, including oaths of loyalty to the Chairman, an elevation of terror as a source of social change, a cult of physical strength, pilgrimages retracing episodes in Mao's biography or providing the opportunity to see him (if only from a distance) and prescribed forms of penitence to rectify transgressions. ${ }^{67}$ Certainly the Red Guards' romanticist and voluntarist perspective on Mao was different to that of the Party establishment. But ultimately, rational and irrational elements in the Mao cult are hard to disentangle. A fine example is the story how People's Liberation Army doctors performed miraculous cures on deaf-mutes by correctly applying Mao's

67 Mitter (2008), pp. 157-63. 
doctrine on contradictions. ${ }^{68}$

What is more interesting in the context of this article is that the Cultural Revolution should not be viewed in isolation. Rather, it formed part of a global wave of social upheavals and transformations that shook both the 'developed' nations of Europe and North America, the struggling nation-states of Latin America and the freshly decolonized Third World ${ }^{69}$ The domestic causes of this upheaval were always complex and varied from country to country and from world region to world region. They were held together, however, by the common framework of the Cold War, which was compounded by the Sino-Soviet split in the early 1960 s, and the changes to the system of nation-states brought about by decolonization, both transformations that were changing the face of the globe. Within this context, Maoism could mean different things to different people, reflecting the more 'pragmatic' or the more 'charismatic' aspects of Maoism (although in practice these aspects may have been hard to distinguish). In largely agriculture-based countries, it might serve as blueprint to a successful strategy of agrarian revolution and guerrilla warfare, sometimes succeeding in bringing together peasants and students. ${ }^{70}$ For the educated urban youth, especially in the 'Western' hemisphere, Mao, along with Ho Chi Minh (1890-1969), Fidel Castro (*1927), Che Guevara (19281967) and others became a key symbol in an emerging 'third world-ism' (tiers-mondisme), a growing concern with the problems faced by the developing world, the Vietnam War being just one example, albeit one of prime importance. Against this backdrop, Mao constituted a powerful counter-image with which to critique and provoke authorities and elder generations. ${ }^{71}$

It has been argued that in its spread across the globe, Maoism proved to be an adaptable and malleable concept - to the extent that there was not one single Maoism, but a spectrum of different Maoisms. ${ }^{72}$ With regard to Western Europe in particular, scholars have pointed to the rather marginal if not entirely insignificant character of Maoist groups and their often highly selective adaptation of Mao's thinking. ${ }^{73}$ The same appears to be true of Mao-oriented organizations in other parts of the world as well, and indeed few of them succeeded in seizing unchallenged state power, with the exception of the Khmer Rouge in Cambodia between 1975 and 1978 and the Communist Party of

68 This was spread through different media, e.g. films, books and magazines. Excerpts from some of these materials are available at $<$ http://www.morningsun.org/red/deafmute/exploring_secrets.html $>$ (accessed 27 February 2013).

69 This global aspect is neatly if somewhat subliminally captured in Cornils and Waters (2010).

70 See Cook (2010), pp. 291-93 and 304-06. For the distinction between 'pragmatic' and 'charismatic' Maoism see Mitter (2008), p. 145.

71 Bourg (2005), p. 386; Diehl (2008), p. 181.

72 See Cook (2010), p. 305; Wemheuer (2008), pp. 11-13.

73 Bourg (2005), pp. 472-73; Wemheuer (2008), p. 20; Wolin (2010), pp. 3-4. 
Nepal (Maoist) since 2006, the latter's success being somewhat anachronistic. ${ }^{74}$ However, overemphasizing the receiving end obscures the fact that the Chinese side took on an active role in this cultural transfer. In fact, the CCP leadership closely monitored protest movements in the world in the late 1960s, seeing China as the centre of the world revolution, and the Red Guards expressed a strong desire to export the revolution to the rest of the world. ${ }^{75}$ Most importantly, perhaps, a number of powerful media that spread the revolutionary message across the world immediately grew out of the Mao cult. These could serve as global icons of protest and revolution, lending themselves to adaptation in various local contexts.

The first of these was the Little Red Book (Mao zhuxi yulu 毛主席語錄, 'Quotations from Chairman Mao'), published under the auspices of the People's Liberation Army in 1964. Until 1971, about 110 million copies appeared in 36 languages (including a Braille version), the official version being supplemented by over 400 local editions. ${ }^{76}$ The Little Red Book was more than a collection of relevant Mao statements for every conceivable situation in life; its materiality served in itself as an icon to be presented ostentatiously. Nobody has appreciated the iconic quality inherent in the book's materiality better than French director Jean-Luc Godard (*1930) in his 1967 film La Chinoiseespecially in the scene where copies of the book are flung at an American toy tank, stopping it instantly in its tracks. ${ }^{77}$ By contrast, a second publication, the Selected Works of Mao Zedong, published in the early 1950s, provided fodder for the intellectual mind. And finally there was Mao's image, popularized in many ways, not the least in the form of Mao badges that were worn as insignia of loyalty by demonstrating Red Guards during the Cultural Revolution. These too made their way abroad; in 1968, the English-language magazine China Reconstructs reported how people across the world were craving for the precious button. ${ }^{78}$ Indeed, the two lines from the Beatles song 'Revolution' stating that "if you go carrying pictures of chairman Mao/You ain't going to make it with anyone anyhow," seem to allude directly to the practice of wearing Mao badges in Britain. ${ }^{79}$ As representatives of popular counterculture, the Beatles, and especially John Lennon (1940-1980), displayed a high degree of ambivalence about a violent revolution in Chinese fashion. But Lennon

74 Cook (2010), pp. 301-04 and 307-11.

75 Brady (1996), pp. 116-22.

76 Leese (2011), p. 108.

77 Godard (2012), 37:12-15.

78 “World's People Eagerly Seek Chairman Mao Badges.” China Reconstructs (May 1968), reprinted in $<$ http://www.morningsun.org/red/badges_cr5_1968.html $>$ (accessed 27 February 2013). For the context cf. Schrift (2001).

79 The two versions of the song are available from $<$ http://steve.hamel.name/songs/revolution.asp $>$ and http://steve.hamel.name/songs/revolution_1.asp (both accessed 27 February 2013). Cf. Platoff (2005), p. 244. I am indebted to Marcus Collins for pointing me to these and related materials. 
sported a Mao badge during a 1970 interview, justifying this on the grounds that Mao was "doing a good job." ${ }^{\prime 80}$

In the global moment created by the upsurge of political religion during the Cultural Revolution in China, Maoist media and iconography linked third-world revolutionaries with firstworld protest culture. To what extent the results can be classified as political religion is a matter of debate, the more so as they varied from place to place. Between 1967 and 1972 the Maoist splinter group popularly known as the Naxalites in India, basing themselves on the 'Little Red Book' as well as on Mao's 'Three Old Essays' adopted Mao's guerrilla tactics to wage a 'people's war'. Despite the tensions before and after the Sino-Indian war of 1962, the Naxalites regarded the Chinese leader as their chairman, beginning what one historian has called the "fanatical worshipping of Mao." Indeed, Charu Mazumdar (1918-1972), chairman of the Communist Party of India (Marxist-Leninist), which became the political driving force of the movement, employed an apocalyptic rhetoric, exhorting his student followers to have faith in Mao Zedong Thought, as it was "smashing the old world and building a new world". ${ }^{82}$ Mazumdar called for the establishment of small work teams, each member equipped with a copy of the Quotations from Chairman Mao, who should share the hardships of poor and landless peasants while at the same time familiarizing them with the sayings of the Chinese leader. The Naxalites also made use of the symbolic materiality of the Quotations, introducing 'red book marriages' whereby a couple could declare themselves husband and wife by exchanging copies of the precious text in front of party members. ${ }^{83}$ Although the Naxalite guerrilla movement was suppressed in the 1970s, it has made a remarkable comeback since the early $2000 \mathrm{~s} .{ }^{84}$ Peru offers a similar example: Here in the 1970s, the guerrillas of the Shining Path (Sendero Luminoso) developed a personality cult reminiscent of Mao around their leader Abimael Guzmán Reynoso (aka Presidente Gonzalez, *1934), who became known to his followers as puka inti, Quechua for "Red Sun," while some nicknamed him more disrespectfully "shampoo," for his alleged ability at brainwashing people. ${ }^{85}$ The Shining Path also followed the Chinese example by making use of big-character posters of sorts and even reciting CCP songs in Mandarin. ${ }^{86}$

In the West European student movement too, adaptations of Maoist ideas and paraphernalia also gave rise to notions of palingenetic renewal. Writing in retrospect, the former German activist Gerd Koenen (*1944) almost echoes Eric Voegelin when he speaks of "a certain apocalyptic

\footnotetext{
80 Wenner (2000), p. 111; cf. Collins (2012), p. 10.

81 Sumanta Banerjee as quoted in Chakrabarti (1990), pp. 59-60.

82 Quoted in Singh (1995): 70.

83 For the "squads" see ibid., 70-71; for the 'red book marriages' Roy 2012, 108-09 and 112-13.

84 Cf. Paul (2013), 1-8; Chakravarti (2008).

85 Gorriti (1992), p. 151.

86 Cook (2010), pp. 304-05.
} 
thinking" exhibited by the movement. China, Koenen goes on to argue, made it possible for German youths to radically reinvent themselves, challenging the older war generation and escaping from the seemingly inexorable rift imposed by the logic of the Cold War. Maoism perfectly fit the idea that somehow there existed a link between third-world liberation movements and the students' attempts at reinventing and refashioning their own society ${ }^{87}$ Echoing another icon of CCP history, student leader Rudi Dutschke (1940-1979) called in February 1968 for a "long march through institutions" that would lead to the creation of counter-institutions or "liberated zones" within bourgeois society. Although at surface level, Dutschke refers to Maoism as a pragmatic strategy, his ideas of antibourgeois forms of social life also appears to foreshadow a complete renewal of society. It is quite possible that related experiments with communal forms of living also had their roots in the study of Chinese Communist texts. ${ }^{88}$

Thus China became a blueprint for radical attempts at renovating society-apocalyptic in that they could only fully be realized through the overthrow of the existing social order. At the same time, China was itself a utopia concretized, as one widely read book argued--a place where human beings and their needs were at the centre of politics and administration. ${ }^{89}$ Surprisingly, this utopia appealed not only to the New Left, but also to conservatives such as the former French minister of education Alain Peyrefitte (1925-1999), the German journalist Klaus Mehnert (1906-1984) or his Swedish colleague Olof Lagercrantz (1911-2002), all of whom visited China in the early 1970s. In their travelogues, they describe China as something akin to an earthly paradise, where the populace scorn wealth, where bureaucracy is reduced to a minimum, where direct democracy is implemented and where the authorities encourage innovation and experiment. These are echoes of the writings of Agnes Smedley (1892-1950), Anna Louise Strong (1885-1970) and Edgar Snow (1905-1972), who had begun to sing Mao's praises as early as the late 1920s and early 1930s. ${ }^{90}$

Whereas most of the Maoist movements in Asia and Latin America were sooner or later repressed by military force (in the case of the Khmer Rouge, by the army of a neighbouring country, Vietnam), the honeymoon of young Western Europeans and North Americans with China came to an end through developments in China itself. Fissures appeared as early as 1972 as a result of China's rapprochement with the United States. They became visible in the wake of US President Nixon's visit to China in February 1972, which publicly and ostensibly involved Mao's persona. In response to this event, a booklet accompanying a record of the German band Ton Steine Scherben released in the same year featured a portrait of Mao with the caption "Mao, Mao, why have you forsaken us?" ${ }^{91}$ Here, the

\footnotetext{
87 Koenen and Diehl (2008), pp. 30 and 36.

88 Ali and Watkins (1998), p. 47.

89 Kuntze (1975), p. 206.

90 Rudolph (1989); cf. Apter (2005).

91 Wemheuer (2008), p. 19.
} 
religious allusion was used to express disappointment at the Chinese leader's retreat from his revolutionary line. When following the death of Mao, the PRC abandoned his radical policies and walked down the capitalist road that Mao had so fervently spoken out against, China ceased to be viewed as the paradise of the workers and peasants that could serve as a model for a radical and miraculous restructuring of 'Western' societies.

As the global moment to which the Mao cult had so greatly contributed gradually petered out across the globe, it also did so in China - with some qualifications, however. Mao was not completely dismantled by the new CCP leadership, and various waves of nostalgia confirm the lingering impression the former Chairman has made on the Chinese population. Films starring Mao's doppelganger Gu Yue 古月 (1937-2005), the sale of kitschy Mao memorabilia from the first decades of the PRC, and forms of red tourism to important places in his life confirm this. The Chairman Mao Memorial Hall on Tian'anmen 天安門 Square in Beijing, in particular, became a site of pilgrimage for the Chinese population. ${ }^{92}$ However, for the time being the Mao cult ceased to function as a political platform, as the CCP turned to other sources of legitimacy.

\section{Vestiges of Political Religion in the Post-Mao Era, 1976-present}

Despite this enduring popularity of certain aspects of the Mao cult in the years after his death, the leadership of party and state quickly embarked on a different course. Its attempts to humanize political power holders was summed up succinctly by then head of state Ye Jianying 葉劍英 (18971986) in his speech on the occasion of the thirtieth anniversary of the People's Republic in October 1979:

\footnotetext{
According to Lenin, those who lead a proletarian party and a Communist state usually are not individuals, but a collective composed of several people referred to as leaders. Organizations at all levels need their leaders... Leading personalities are not gods, they cannot but have defects and [commit] mistakes, [hence] they should not be deified. ${ }^{93}$
}

As well as distancing themselves from the Mao cult, the new leaders also sought to undermine its ideological underpinnings. For Deng Xiaoping 鄧小平 (1904-1997), the emerging paramount leader, the core of the Mao Zedong ideas consisted not in the concept of class struggle, but in 'seeking truth from facts' (shishi qiu shi 實事求是). In establishing practice as the sole criterion of truth, Deng was supported by Hu Yaobang 胡耀邦 (1915-1989), who until his dismissal as Secretary

\footnotetext{
92 Barmé (1996); Wagner (1992 a).

93 Ye Jianying (1979), p. 26.
} 
General of the CCP in 1987 was one of his closest political associates. Deng and his followers succeeded in establishing a discursive framework that forced party cadres to declare themselves in favour of the new political line of the party, no matter whether they were convinced of it or not. ${ }^{94}$ This shift paved the way for China's new economic policy; at the same time, it was a major departure from the emphasis on individual faith and inner transformation characteristic of the Mao era. Propagating the 'liberation of thought' (jiefang sixiang 解放思想), the CCP under Deng had effectively been stripped off all signs of political religion.

The approach of the early Deng Xiaoping years was not to last, however. From the late 1970s, the CCP struggled with political and social dissent embodied, among others, in the democracy movements of 1978/79 and 1989. The brief appearance of the 'Goddess of Democracy' in Tian'anmen Square in late May and early June 1989 was a double appropriation, drawing on a global symbol of individual freedom and democratic government, the Statue of Liberty in New York, which itself merges religious imagery into a secular political discourse. Other global symbols included the 'International' as the hymn of the movement and the wearing of white headbands, adopted from prodemocracy protests in Korea and the Philippines. At the same time, the Goddess' seeming dialogue with the portrait of Mao hanging from Tian'anmen Gate, captured in photographs at the time, could also be read as invoking the messianism associated with Mao against a dictatorial and corrupt party elite. $^{95}$

In reaction to the two democracy movements, which it suppressed ruthlessly, the CCP tried to redefine both its ideology and its position within the world at large. The Four Basic Principles, laid down in 1979, contained those features that the party was determined to hold on to: MarxismLeninism and Mao Zedong Thought, the leadership of the CCP, Socialism and the dictatorship of the proletariat. The formulation, however, was vague and more geared towards preventing the people from challenging the party-state. ${ }^{96}$ In 1992, three years after the brutal crackdown on the demonstrators at Tian'anmen Square, the CCP officially adopted Deng Xiaoping theory, which included as developmental goal a "socialism with Chinese characteristics" (you Zhongguo tese de shehuizhuyi 有中國特色的社會主義). This formula pointed to a specific Chinese goal of modernization that would resemble neither Soviet-style socialism nor the liberal-democratic capitalism of the West. The deliberate camouflaging of the 'Western' origins of socialism was an echo of the late-nineteenth century ti-yong 體用 formula, conceived by Confucian scholars in an attempt to strengthen China by importing 'Western' technology while at the same keeping 'Western'

\footnotetext{
94 For this shift see Zhang Wei-Wei (1996), pp. 23-28.

95 Wagner (1992 b), pp. 330-42.

96 Zhang Wei-wei (1996), pp. 29-32.
} 
ideas at bay. ${ }^{97}$

Since the early 1990s, successive CCP leaders as well as party propaganda have introduced comprehensive interpretations of China's past, present and future that to some extent relate the idea of a fundamental transformation of Chinese society. Perhaps the most obvious example is the officially sponsored resurgence of Chinese nationalism in the 1990s. A case in point is the well-known 1994 poster series on 'patriotic education. ${ }^{98}$ The four posters in the series address different themes: pride in China's ancient civilization, indignation at the unforgettable experience of China's humiliation by imperialism, fond memories of China's revolution from 1911 to the Communist takeover in 1949 and finally, satisfaction at modern technology, which will catapult China to the forefront of the twentyfirst century world. Whilst identifying the enemies who have hindered China's progress, the end result will be a new nation whose progress is symbolized by the ability to explore outer space.

Interestingly, a similar trajectory, albeit with a different focus, can be found in Jiang Zemin's 江澤民 (*1926) explanations of his ‘Three Represents' (San ge daibiao 三個代表), promulgated in 2000. Jiang, who succeeded Deng Xiaoping as paramount leader, divides the "more than seventy-year history" of the CCP into the three stages of revolution, reconstruction and reform. In each of these stages, the party "always has represented the demands of China's progressive productive forces, represented the direction of the advance of China's progressive culture, represented the fundamental interests of the broadest [masses] of the people." "99 These 'Three Represents,' according to Jiang, are also the key to China's future development, enabling the reconstruction of the party - which should be enabled to accept capitalists as members - and the "self-perfection and development" of a "socialism with Chinese characteristics." 100 Jiang thus presents the sanitized history of an unblemished Party, while at the same time connecting it with the promise of a perfect future.

Jiang’s successor Hu Jintao 胡錦濤 $(* 1942)$ chose yet another approach, attempting to even out social imbalances that have arisen as a consequence of the reform process: by declaring a moderately affluent society (xiaokang shehui 小康社會) as China's developmental goal, he borrowed heavily from Confucian utopianism and in particular Kang Youwei's 康有為 (1858-1927) Datong shu 大同書 (The book of Supreme Unity). ${ }^{101}$ At the same time, his Eight Honours and Eight Shames (Ba rong ba chi 八榮八恥), proclaimed two years later, offer a moral code for every citizen. Its elements - such as love of the country and serving the people, embracing science and education, hard work,

\footnotetext{
97 Wakeman (2002), p. 160.

98 The posters and a commentary are available from < $\underline{\mathrm{http}} / / / \mathrm{www}$.chineseposters.net/themes/patrioticeducation-1994.php $>$ (accessed 9 July 2013).

99 Jiang Zemin (2001), p. 2.

100 Jiang Zemin (2002), p. 583.

101 The term was first used by Deng Xiaoping in the 1980s; cf. Tomba (2009).
} 
respect for the law and discipline - are adapted to serve the vision of a modernizing China at the outset of the twenty-first century. A DVD from the early $\mathrm{Hu}$ Jintao era underlays pictures of a peaceful, harmonious and modern Chinese society with songs incorporating the eight maxims. ${ }^{102}$

Though these attempts differ in their outlook, all of them are underpinned by a tightly circumscribed role of history in public life. In Communist China, understanding the past has always been placed under party supervision; at any point in recent history, its interpretation has followed the official party line of the day. With other symbols of Communist ideology on decline, the sacralization of Chinese history was brought more sharply into relief. Its essence is neatly captured by a propaganda poster issued in 1984 (Fig. 2): At the centre, the image shows a hand holding a book - a direct reference to the shape of the Little Red Book, except that this time, it is a Modern History of China covered in blue. Yellow waves alluding to sunbeams as well as scenes from the Monument to the People's Heroes on Tian'anmen Square are both reminiscent of the Cultural Revolution. At the same time, the caption evokes the connection between history and patriotism: "To love the country one must first know its history - the deeper the knowledge, the more eager the love." The religious imagery surrounding the themes of history and patriotism endows this poster with a significance beyond its original context, the campaign against bourgeois liberalization.

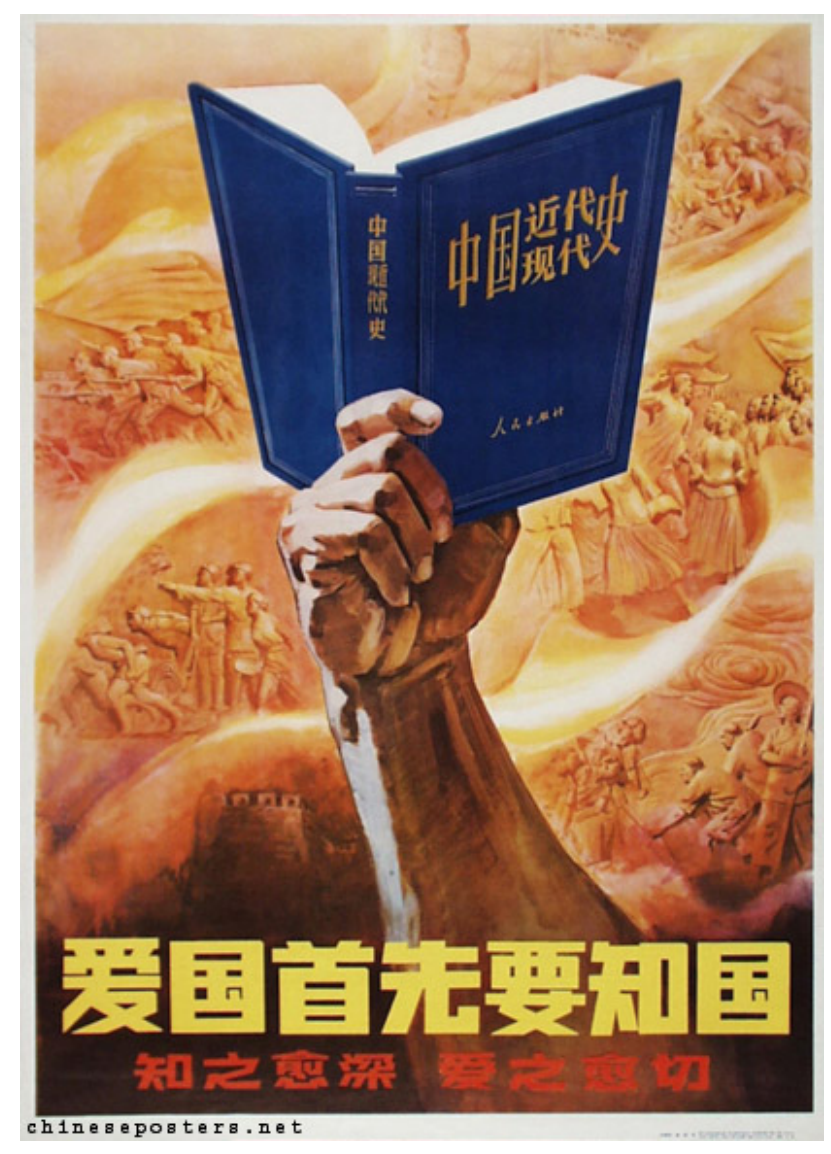

102 "Ba rong ba chi” gequ san ban huicui (2006). 
Figure 2: Ai guo shouxian you zhi guo-zhi zhi yuhen ai zhi yu qie 爱国首先要知国一知之愈深爱之愈切 [To love the country one must first know its history-the deeper the knowledge, the more eager the love], propaganda poster by Sha De'an 啥德安 and Li Yang 李阳, 1984, International Institute for Social History (Amsterdam), Stefan Landsberger collection, BG E13/489.

The CCP has taken great pains to immunize Chinese history against unwelcome interpretations, both domestically and abroad. A particularly sensitive issue is the history of imperialism precisely because it has a global dimension involving other parties. In the 1990s, the concept of 'national humiliation' (guochi) made a spectacular comeback across all kinds of media, indicating a discursive shift from heroic resistance (which had dominated the memory of imperialism under Mao) to Chinese suffering and victimization. ${ }^{103}$ The conflict between China and the Vatican in October 2000 offers a good example of how the CCP has tried to defend its history against competing interpretations in an increasingly globalizing world. It revolved around the canonization of 120 Chinese martyrs by Pope John Paul II (1920-2005) on 1 October of that year. The date was chosen by the church because it is the feast of Saint Thérèse of Lisieux (1873-1897), a patron saint of foreign missions. ${ }^{104}$ As the majority of the 120 persons selected for canonization were Chinese, the ceremony can also be viewed as reflecting the growing recognition of non-European contributions to a global church. From the perspective of CCP, however, this was an interference with the official Chinese interpretation of history, the more so as the ceremony was scheduled for Chinese National Day. From late September into the first week of October, Chinese media conducted a massive campaign against the Vatican, no doubt with official backing. China's official 'patriotic' religious associations were also quoted as supporting the stance of party and government. ${ }^{105}$ Newspaper articles denounced the

${ }^{103}$ Cohen (2003); Gries (2004), pp. 43-53.

104 Clark (2010), p. 54.

105 The following discussion is based on the coverage in Renmin Ribao between 25 September and 6 October 2000. The majority of articles also appeared in Guangming Ribao at the same time, suggesting that the press coverage had official backing. For the role of religious associations "Jiu Fandigang wushi Zhongguo jiaohui zhuquan ni cefeng suowei shengren renshi, Zhongguo Tianzhu Aiguohui Zhongguo Tianzhujiao Zhujiaotuan fabiao shengming 就梵蒂冈无视中国教会主权拟册封所谓圣人, 中国天主教爱国会中国天主教主教团 发表声明 [In response to the Vatican's plan to disregard the sovereignty of the Chinese church by canonizing the so-called saints. The Chinese Patriotic Catholic Association and the Chinese Catholic Bishops Conference publish a declaration," Renmin Ribao 27 September 2000, p. 1; “Jiu Fandigang waiqu cuangai lishi ni xuanbu cefeng suowei 'shengren' shi. Zhongguo Jidujiao Sanzi Yundong Weiyuanhui Zhongguo Jidujiao Xiehui fabiao shengming 就梵蒂冈歪曲篡改历史拟宣布册封搜位〈圣人〉 中国基督 教协会发表声明 [In response to the Vatican's distortion and falsification of history by planning to proclaim the canonization of the so-called 'saints.' The National Committee of the Patriotic Three-Self Movement of the Protestant Churches in China and the China Christian Council publish a declaration," Renmin Ribao, 28 
canonization of the "so-called 'saints'," arguing that the Vatican was consciously attempting to manipulate and falsify history. The understanding of history underpinning the press coverage leaves no room for different interpretations; deviations from the one true version sanctioned by the party are viewed as distortion, fabrication, as a "provocation of the Chinese people" or even as "anti-Chinese activities (fan Hua huodong 反華活動)." ${ }^{106}$ At the same time, the 'correct' interpretation of history, in which professional historians joined the journalists, was based on the vilification of Catholic missionaries. These had committed 'crimes' (zui 罪) against the Chinese people: not content with supporting imperialist politics and forcibly occupying land on which to build churches, they had committed more heinous misdeeds, abusing, seducing or raping Chinese women (in particular Christians). ${ }^{107}$ Finally, commentators strongly emphasized the difference between the China of today and that of the nineteenth and early twentieth centuries. The message is that China was weak then, but is much stronger today and will be able to successfully resist any encroachments from outside forces.

It goes without saying that such a discourse is not only about the past. It is about China's role in an increasingly globalizing world. And it must be seen in connection with events such as the NATO bombing of the Chinese embassy in Belgrade in 1999 and the ensuing outrage in China, or the anti-Japanese demonstrations across China in $2005 .{ }^{108}$ In this logic, if China is striving to attain a leading global role, it must overcome the “containment policy” (ezhi zhengce 遏制政策) of the West and in particular the United States. This view emanates not only from government propaganda, but also from more popular expressions of nationalism, such as the 1996 bestseller China Can Say No, which is itself modelled on a Japanese pamphlet. ${ }^{109}$ What is left of the apocalyptic dimension of Chinese politics, then, is the necessity of overcoming external adversaries in order to emerge as a

September 2000, p. 1; “Wo guo Fojiao Yisilanjiao Daojiao quanguoxing tuanti fenbie juxing zuotanhui. Qianglie fandui Fandigang jie 'shengren' gao fan Hua huodong 我国佛教伊斯兰教道教全国性团体分别 举行座谈会. 强烈反对梵蒂冈借〈圣人〉搞反华活动 [Our country's national Buddhist, Islamic and Daoist organizations hold meetings. Resolutely resist the Vatican's use of 'saints' to conduct anti-Chinese activities]," Renmin Ribao, 4 October 2000, p. 1.

${ }^{106}$ Apart from the material in the previous footnote, cf. also the commentary by an anonymous editorialist, “Fandigang 'feng sheng' shi dui Zhongguo renmin de yanzhong tiaoxin 梵蒂冈〈封圣〉是对中国人民的 严重挑畔 [The Vatican 'canonization of saints' is a serious provocation of the Chinese people]," Renmin Ribao, 3 October 2000, p. 1.

${ }^{107}$ Zhen Shi 甄实, “Ma Lai yu Di-er ci yapian zhanzheng 马赖与第二次鸦片战争 [Auguste Chapdelaine and the Second Opium War]," Renmin Ribao, 29 September 2000, p. 3; Shi Yan 史岩, “Jiekai suowei 'shengren' de mianmu 揭开所谓〈圣人〉的面目 [Exposing the ugly face of the so-called 'saints']," Renmin Ribao, 3 October 2000, p. 2 - the latter an echo of 1920s anti-imperialist rhetoric. For the context cf. Clark (2010).

${ }^{108}$ Gries (2004), pp. 128-33; Reilly (2006), pp. 208-11.

${ }^{109}$ Song Qiang et al. (1996), especially pp. 51-52. 
truly global player.

In the post-Mao era, the CCP has replaced the 'faith' in the political leadership that was such a defining feature of Mao's rule with a more empirically oriented and increasingly technocratic understanding of politics. The party has promulgated a new code of social ethics aiming at the creation of social harmony through correct practice--a strategy that, it is true, borrows heavily from Confucianism and is more in line with Chinese modes of 'doing religion' than with the faith-based understanding of religion adopted from the 'West." ${ }^{110}$ The same can be said of the (propagandistic) attempts of creating a middle-class society, which is both a realistic strategy and draws on Confucianinspired utopianism. At the same time, the Party has sanitized its own history and sacralized that of China at large. This can be viewed as a response to the domestic and international challenges in a rapidly globalizing world. While it echoes some of the defining features of political religion - in particular the immaculate image of the Party and its leadership, the symbolism surrounding the nation and the notion that China must overcome contending forces to attain its rightful place in the world -, it bears more resemblance to the pre-1920 period than to Guomindang China or the Mao era.

\section{Conclusion}

The trajectory of political religion in twentieth-century China owes much to China's standing in the world at large. It grew out of attempts at overcoming China's perceived international weakness, which was always bound up with the country's domestic problems. At the same time, it can be viewed as a specifically Chinese response to one of the great global challenges of the twentieth century: the decline of a transcendent legitimacy of political authority. In the 1920s, China became part of a global revolutionary project that sought to unite the oppressed peoples of the world under the leadership of the Soviet Union against capitalist imperialism. Although this project was soon abandoned by the Soviet leadership itself, it had a lasting impact on Chinese politics. The Nationalists, who had severed their ties with Soviet Communism as early as the late 1920s, adapted the Soviet model of political religion and mixed it with Christian influences, despite explicitly disavowing the latter. For the Guomindang, faith in the late leader Sun Yatsen and in the party ideology he created was essential in bringing about a domestically unified and internationally strengthened China. Political rituals centred around the memory of Sun and geared towards creating a revolutionary work ethic became the means to inculcate this faith amongst the political and social elites, whose successful mobilization would enable China to become part of a global modernity. However, this also required struggles to overcome obstacles and foes in order to win through to the ultimate goal-a vision which constitutes the 'apocalyptic' element of the GMD's political religion.

In principle, the political religion of the CCP propagated throughout the Mao era stemmed

${ }^{110}$ Chau (2011), p. 549. 
from the same ideological background and served the same goals. But not only did they penetrate more deeply and more effectively into Chinese society, they also became part of a global moment in the 1960s and 1970s. This united different constituencies-a youthful urban counterculture in the 'West,' revolutionary guerrilla movements in the Third World. While for the latter, adopting Mao's strategies seemed to reflect a straightforward logic, this was not the case for the former. In Western Europe and North America, an increasing receptivity towards the emerging Third World played a far greater role. The politically religious dimension Maoism could inscribe itself into this trend. But this process was not exclusively determined by the receiving end: China's essential contribution to the revolutionary global moment consisted in producing powerful symbols-most notably Mao's portrait and the Little Red Book as well as other Mao writings - that had an appeal for different constituencies.

As political religions, the ideologies of the GMD and of the CCP in the Mao era shared a number of characteristics: Both placed a strong emphasis on faith and invididual as well as collective transformation, based on the cult of a political leader. In abandoning these, the post-Mao Communist leadership took an altogether different approach. However, the global environment within which it operated looked more akin to the situation of Guomindang China than to the global moment of the 1960s and 1970s. Although many emerging economies could look to the Chinese developmental model for guidance and 'Western' enterprises could not resist the allure of the Chinese market, CCP ideology was hardly a selling point. 'Western' public opinion in particular, having somewhat belatedly discovered the atrocities during Mao's reign, was increasingly hostile, pointing to China's human rights violations as well as its increasing military build-up and heightened nationalism. In this context, vestiges of political religion continue to exist in the form of a whitewashed party history, the sacralization of national history, the apocalyptic identification of enemies and obstacles to be overcome, the propagation of a moral code that can unify the population domestically and strengthen China vis-à-vis the challenges from abroad and finally the vision of a harmonious future society and a rise of China's power at the global level.

With the possible exception of the democratic movement of 1989, the Mao cult ceased to be used as a political platform after the chairman's death in 1976 - until very recently: When the party chairman of Chongqing 重慶 Bo Xilai 薄熙來 (*1949) initiated a "red culture movement" reminiscent of Mao-era mass campaigns in 2011, he may well have intended this to be part of a bid for power at the Party's centre. ${ }^{111}$ Although Bo's expulsion from the party the following year put a stop to his personal ambitions, it would seem that the new party chairman, Xi Jinping 習近平, who took office in late 2012, has also appropriated elements from the Mao cult. In June 2013, the party launched a "campaign to realize the Party's mass line education" (dang de qunzong luxiang jiaoyu shixian yundong 黨的群眾路線教育實現運動), with Xi himself presiding over self-criticism

111 Branigan (2011). 
sessions. A new edition of the Quotations from Chairman Mao is scheduled for November of the same year. This is certainly more than a move to appease left-wing adherents of Bo Xilai. ${ }^{112}$ Each of Mao's successors has sought to make his imprint on the ideological development and-more broadly speaking - the political culture of party, state and society. And for Xi, elements of Maoist politics may appear as an expedient tool to distinguish himself from his predecessors and establish his authority as a leader. All of this clearly does not imply a return to the class struggle of the Mao era. But it indicates how elements of political religion inherited from the twentieth century may still shape China's contemporary politics. What is also obvious is that in shaping its political culture, present-day China can rely on a purely national heritage. The global processes by which the idea of political ideologies as beliefs was introduced in China as well as the ideas of apocalypse and palingenesis that the Mao cult radiated back into the wider world now appear to belong to history.

\section{Bibliography}

\section{Unpublished Documents}

AH Guoshiguan 國史館 [Academia Historica], Taipei, Taiwan

GMD Zhongguo Guomindang Zhongyang Weiyuanhui Dangshi Weiyuanhui 中國國民黨 中央委員會黨史委員會 [Archives of the Historical Commission, Central Committee of the GMD], Taipei

ZDELD Zhongguo Di-er Lishi Dang'anguan 中国第二历史档案馆 [Second Historical Archives of China], Nanjing

\section{Newspapers}

Guangming Ribao 光明日报 (September-October 2000)

Renmin Ribao 人民日报 (September-October 2000)

\section{Published sources and literature}

Ali, Tariq and Susan Watkins (1998). 1968: Marching in the Streets. New York: Free Press.

Anon (1927). “Zongli jinianzhou de yiyi zai nali 總理紀念週的意義在那裏 [Where is the meaning of the Weekly Remembrance for the Premier]?” Guangdong xingzheng zhoubao 廣東行政週 報 6-7, p. 7.

Apter, David E. (1995). "Discourse as Power: Yan'an and the Chinese Revolution.” In: Tony Saich and Hans van de Ven (eds.), New Perspectives on the Chinese Communist Revolution.

112 See, for example, Branigan (2013); Forde (2013); Zhuang Feng (2013). 
Armonk, NY: Sharpe, pp. 193-234.

Apter, David E. (2005). "Bearing Witness: Mao as Religion." Copenhagen Journal of Asian Studies 22, pp. 5-37.

Aron, Raymond (1957). The Opium of the Intellectuals. New York: Doubleday.

Asad, Talal (2003). Formations of the Secular: Christianity, Islam, Modernity. Stanford, CA: Stanford University Press.

Ashiwa, Yoshiko and David L. Wank (2009). "Making Religion, Making the State in Modern China: An Introductory Essay." In: Yoshiko Ashiwa and David L. Wank (eds.), Making Religion, Making the State: The Politics of Religion in Modern China. Stanford, CA: Stanford University Press, pp. 1-21.

“Ba rong ba chi” gequ san ban huicui 八荣八耻歌曲三板荟萃 [A Collection of Songs on the “Eight Honours and Eight Shames" in Three Versions] (2006). DVD Guangzhou: Nanhaichao Yinxiang Chubanshe.

Barmé, Geremie (1996). Shades of Mao: The Posthumous Cult of the Great Leader. Armonk, NY: Sharpe.

Bastid-Bruguière, Marianne (2002). "Patterns of propaganda organization in the nationalrevolutionary movement in China in the 1920s." In: Mechthild Leutner et al. (eds.), The Chinese Revolution in the 1920s: Between Triumph and Disaster. London: Routledge Curzon, pp. 3-29.

Bendix, Reinhard (1980). Kings or People: Power and the Mandate to Rule. Berkeley, CA: University of California Press (first published in 1978).

Bergère, Marie-Claire (1994). Sun Yat-sen. Paris: Fayard.

Bourdieu, Pierre (1971). "Genèse et structure du champ réligieux." Revue française de sociologie 12, pp. 295-334.

Bourdieu, Pierre (2009). “Genese und Struktur des religiösen Feldes.” In: Pierre Bourdieu, Religion. Schriften zur Kultursoziologie 5, eds. Franz Schultheis and Stephan Egger. Konstanz, Germany: UVK Verlagsgesellschaft, pp. 30-90.

Bourg, Julian (2005). “The Red Guards of Paris: French Student Maoism of the 1960s." History of European Ideas 4, pp. 472-90.

Brady, Anne-Marie (1996). "Red and Expert: China's 'Foreign Friends' in the Great Proletarian Cultural Revolution, 1966-1969." China Information 11:2-3, pp. 110-37.

Branigan, Tania (2011). "Red songs ring out in Chinese city's new cultural revolution." The Guardian, 22 April, <http://www.guardian.co.uk/world/2011/apr/22/red-songs-chinesecultural-revolution $>$ (accessed 1 June 2013).

Branigan, Tania (2013). “Mao's Little Red Book to get revamp. New version of Quotations from Chairman Mao, the world's second most published book, to hit Chinese shelves in November." The Guardian, 27 September, < http://www.theguardian.com/world/2013/sep/27/mao-little-red-book-revamp> (accessed 13 
November 2013).

Chakrabarti, Sreemati (1990). China and the Naxalites. Delhi: Radiant Publications.

Chakravarti, Sudeep (2008). Red Sun. Travels in Naxalite Country. New Delhi: Viking/Penguin.

Chao, Emily (1999). "The Maoist Shaman and the Madman: On Ritual Bricolage, Failed Ritual, and Failed Ritual Theory." Cultural Anthropology 14, pp. 505-34.

Chau, Adam Yuet (2011). "Modalities of doing religion and ritual polytropy: evaluating the religious market model from the perspective of Chinese religious history." Religion 41, pp. 547-68.

Chen Duxiu (n.d.) 陳獨秀. Wangguo pian 亡國篇 [Essay on the downfall of the nation]. $<\underline{\text { http://sangle.web.wesleyan.edu/etext/late-qing/chen-wang_guo.html }>}$ (accessed 4 July 2013).

Chen Yunqian 陈蕴茜 (2005). “Shijian, yishi weidu zhong de 'Zongli jinianzhou’ 时间、仪式维度 中的《总理纪念周》[The 'Weekly Rembrance of the Party Leader' in spatial and ritual measure)." Kaifang shidai 开放时代 2005:4, pp. 63-81.

Chen Yunqian 陈蕴茜 (2009). Chongbai yu jiyi: Sun Zhongshan fuhao de jiangou yu chuanbo 崇拜 与记忆. 孙中山符号的建构与传播 [Worship and memory. The construction and dissemination of Sun Yatsen as a symbol]. Nanjing: Nanjing Daxue Chubanshe.

Clark, Anthony E. (2010). "Rape, Baptism and the 'Pig' Religion: Images of Foreign Missionaries During the Late Nineteenth Century." In: Anthony E. Clark (ed.), Beating Devils and Burning Their Books: Views of China, Japan, and the West. Ann Arbor, MI: Association for Asian Studies, pp. 43-81.

Cohen, Myron L. (1992). "Religion in a State Society: China," < http://afe.easia.columbia.edu/cosmos/main/religion_in_state_society.pdf $>$ (accessed 10 July 2013).

Cohen, Paul A. (2003). "Remembering and forgetting national humiliation in twentieth-century China." In: Paul A. Cohen, China unbound: Evolving perspectives on the Chinese past. London: RoutledgeCurzon, pp. 148-84.

Collins, Marcus (2012). "The Beatles' Politics." British Journal of Politics and International Relations, pp. 1-19.

Conrad, Sebastian and Dominic Sachsenmaier (2007). "Introduction: Competing Visions of World Order: Global Moments and Movements, 1880-1930." In: Sebastian Conrad and Dominic Sachsenmaier (eds.), Competing Visions of World Order. Global Moments and Movements, 1880-1930. New York: Palgrave Macmillan, pp. 1-25.

Cook, Alexander C. (2010). “Third World Maoism.” In: Timothy Cheek (ed.), A Critical Introduction to Mao. Cambridge: Cambridge University Press, pp. 288-312.

Cornils, Ingo and Sarah Waters (eds.) (2010). Memories of 1968: International Perspectives. Oxford: Lang.

Dash, Satya Prakash (2006). Naxal Movement and State Power (with special reference of [sic] Orissa). New Delhi: Sarup \& Sons. 
Diehl, Laura K. (2008). "Die Konjunktur von Mao-Images in der bundesdeutschen '68er'Bewegung." In: Sebastian Gehrig, Barbara Mittler and Felix Wemheuer (eds.), Kulturrevolution als Vorbild? Maoismen in deutschsprachigen Raum. Frankfurt am Main: Lang, pp. 179-201.

Duara, Prasenjit (1991). "Knowledge and Power in the Discourse of Modernity: The Campaigns against Popular Religion in Early Twentieth-Century China." Journal of Asian Studies 50, pp. 67-83.

Elleman, Bruce A. (1997). Diplomacy and Deception: The Secret History of Sino-Soviet Diplomatic Relations, 1917-1927. Armonk, NY: Sharpe 1997.

Elleman, Bruce A. (2002). Wilson and China: A Revised History of the Shandong Question, Armonk, NY: Sharpe.

Elman, Benjamin A. (2005). On Their Own Terms: Science in China, 1550-1900. Cambridge, MA: Harvard University Press.

Feuchtwang, Stephan (1978). "School Temple and City God." In: Arthur P. Wolf (ed.), Studies in Chinese Society. Stanford, CA: Stanford University Press, pp. 103-30.

Forde, Brendan (2013). “China's 'Mass Line' Campaign,” http://thediplomat.com/chinapower/chinas-mass-line-campaign/ (accessed 13 November 2013).

Gao Hua 高華 (2000). Hong taiyang shi zenyang shengqi de: Yan'an Zhengfeng yundong de lailong qumai 紅太陽是怎樣升起的. 延安整風運動的來龍去脈 [How did the red sun rise? The origins and impact of the Yan'an Rectification Movement]. Hong Kong: Chinese University Press.

Godard, Jean-Luc (2012). La Chinoise. DVD: Gaumont Vidéos (first released in 1967).

Goossaert, Vincent and David A. Palmer (2011). The Religious Question in Modern China. Chicago, IL: Chicago University Press.

Gentile, Emilio (2006). Politics as Religion. Princeton, NJ: Princeton University Press 2006.

Gerth, Karl G. (1998). "Consumption as Resistance: The National Products Movement and AntiJapanese Boycotts in Modern China." In: Harald Fuess (ed.), The Japanese Empire in East Asia and Its Postwar Legacy. Munich: Iudicium, pp. 119-42.

Gorriti, Gustavo (1992). "Shining Path's Stalin and Trotsky." In: David Scott Palmer (ed.), The Shining Path of Peru. London: Hurst, pp. 149-70.

Gries, Peter H. (2004). China's New Nationalism: Pride, Politics and Diplomacy. Berkeley, CA: University of California Press.

Griffin, Roger (1991). The Nature of Fascism. London: Routledge.

Gu Weijun 顾维钧 (1989). Gu Weijun huiyilu 顾维钧回忆录 [Records of Wellington Koo]. Vol. 11. Beijing: Zhonghua Shuju.

Hung, Chang-tai (1996). "The Politics of Songs: Myths and Symbols in the Chinese Communist War Music. 1937-1949." Modern Asian Studies 30, pp. 901-29.

Harrison, Henrietta (2000). The Making of the Republican Citizen: Political Ceremonies and Symbols 
in China 1911-1929, Oxford: Oxford University Press.

Harrison, Henrietta (2001). China: Inventing the Nation. London: Arnold.

“Jinianzhou tiaoli 紀念週條例” [Regulations for the Weekly Remembrance of the Premier” (1926). Guomin zhengfu gongbao 國民政府公報 16:寧:4, 12 February 1926, pp. 1-2.

Jiang Zemin 江泽民 (2001). “Zai xin de lishi tiaojian xia, women ruhe zuodao ‘San ge daibiao’ 在新 的历史条件下，我们如何做到〈三个代表〉 [How are we to carry out the "Three Represents' under new historical circumstances].” In: Jiang Zemin, Lun San ge daibiao 论三 个代表 [On the Three Represents]. Beijing: Zhongyang Wenxian Chubanshe, pp. 1-6.

Jiang Zemin lun you Zhongguo tese de shehuizhuyi 江泽民论有中国特色的社会主义 [Jiang Zemin on Socialism with Chinese characteristics] (2002). Beijing: Zhongyang Wenxian Chubanshe.

Klein, Thoralf (2014). "The Missionary as Devil. Anti-Christian Demonology in China, 1860-1930." In: Judith Becker and Brian Stanley (eds.), Europe as the Other: External Perspectives on European Christianity. Göttingen: Vandenhoeck \& Ruprecht, pp. 117-46.

Knecht, Michi and Jörg Feuchter (2008). "Introduction: Reconfiguring Religion and Its Other." In: Heike Bock, Jörg Feuchter and Michi Knecht (eds.), Religion and Its Other: Secular and Sacral Concepts and Practices in Interaction. Frankfurt am Main: Campus, pp. 9-20.

Koenen, Gerd and Laura K. Diehl (2008). "Mao als Mona-Lisa der Weltrevolution.” In: Sebastian Gehrig, Barbara Mittler and Felix Wemheuer (eds.), Kulturrevolution als Vorbild? Maoismen in deutschsprachigen Raum. Frankfurt am Main: Lang, pp. 27-37.

Kreiser, Klaus (2011). Atatürk. Eine Biographie. Munich: Beck (first published in 2008).

Kuntze, Peter (1973). China - die konkrete Utopie. Munich: Nymphenburger Verlagshandlung.

Kuo Heng-yü et al. (eds.) (1996). RKP(B), Komintern und die national-revolutionäre Bewegung in China. Dokumente. Vol. 1: 1920-1925. Paderborn: Schöningh.

Kuo Ya-pei (2008). "Redeploying Confucius: The Imperial State Dreams of the Nation, 1902-1911." In: Mayfair Mei-hui Yang (ed.), Chinese Religiosities: Afflictions of Modernity and State Formation. Berkeley, CA: University of California Press, pp. 65-84.

Lackner, Michael and Natascha Vittinghoff (eds.) (2004). Mapping Meanings: The Field of New Learning in Late Qing China. Leiden: Brill.

Landsberger, Stefan (2002). "The Deification of Mao: Religious Imagery and Practices during the Cultural Revolution and Beyond." In: Woei Lien Chong (ed.), China's Great Proletarian Cultural Revolution: Master Narratives and Post-Mao Counter Narratives. Lanham, MD: Rowman \& Littlefield, pp. 139-84.

Lee, Nelson K. (2009). "How is a political public space made?-The birth of Tiananmen Square and the May Fourth Movement." Political Geography 28, pp. 28-42.

Leese, Daniel (2011). The Mao Cult: Rhetoric and Ritual in China's Cultural Revolution. Cambridge: Cambridge University Press.

Leng, Shao-chuan and Norman D. Palmer (1976). Sun Yat-sen and Communism. New ed. Westport, CT: Greenwood Press (first published in 1960). 
Li Yuzhen 李玉貞 (1996). Sun Zhongshan yu Gongchan Guoji 孫中山與共產國際 [Sun Yatsen and the Communist International]. Taipei: Zhongyang Yanjiuyuan Jindaishi Yanjiusuo.

Luo Zhitian (1993). "National Humiliation and National Assertion: The Chinese Response to the Twenty-One Demands.” Modern Asian Studies 27, pp. 297-319.

Luo Zhufeng (1991). Religion under Socialism in China. Armonk, NY: Sharpe.

Macey, Samuel L. (2010). The Dynamics of Progress: Time, Method and Measure. Athens, GA: University of Georgia Press (first published in 1989).

Manela, Erez (2007). The Wilsonian Moment: Self-Determination and the International Origins of Anti-Colonial Nationalism. Oxford: Oxford University Press 2007.

Mitter, Rana (2004). A Bitter Revolution: China's Struggle with the Modern World. Oxford: Oxford University Press.

Mitter, Rana (2008). "Maoism in the Cultural Revolution: A Political Religion?" In: Roger Griffin, Robert Mallett and John Tortorice (eds.), The Sacred in Twentieth-Century Politics: Essays in Honour of Professor Stanley G. Payne. Basingstoke u. a.: Palgrave Macmillan, pp. 143-68.

Murdock, Michael G. (2006). Disarming the Allies of Imperialism: The State, Agitation, and Manipulation during China's Nationalist Revolution, 1922-1929. Ithaca, NY: East Asia Program, Cornell University.

Musgrove, Charles D. (2007). "Monumentality in Nanjing's Sun Yat-sen Memorial Park." Southeast Review of Asian Studies 29, pp. 1-19.

Nedostup, Rebecca Allyn (2007). "Civic Faith and Hybrid Ritual in Nationalist China." In: Dennis A. Washburn and Kevin Reinhart (eds.), Converting Cultures: Religion, Ideology and Transformations of Modernity. Leiden: Brill, pp. 27-56.

Nedostup, Rebecca (2008). "Ritual Competition and the Modernizing Nation-State." In: Mayfair Meihui Yang (ed.), Chinese Religiosities: Afflictions of Modernity and State Formation. Berkeley, CA: University of California Press, pp. 87-112.

Nedostup, Rebecca (2009). Superstitious Regimes: Religion and the Politics of Chinese Modernity. Cambridge, MA: Harvard University Asia Center.

Pantsov, Alexander V. (2002). "Bolshevik Concepts of the Chinese Revolution, 1919-1927." In: Mechthild Leutner et al. (eds.), The Chinese Revolution in the 1920s: Between triumph and disaster. London: Routledge Curzon, pp. 30-43.

Passmore, Kevin (2002). Fascism: A Very Short Introduction. Oxford: Oxford University Press.

Paul, Santosh (2013). "Introduction." In: Santosh Paul (ed.), The Maoist Movement in India. Perspectives and Counterperspectives. London: Routledge.

Pi Houfeng 皮后锋 (1995). “Zhongguo jindai guoge kaoshu 中国近代国歌考述 [An examination of China's national anthems in the modern period].” Jindaishi yanjiu 近代史研究1995:2, pp. 260-71.

Platoff, John (2005). “John Lennon, 'Revolution,' and the Politics of Musical Reception.” Journal of Musicology 22, pp. 241-67. 
Poon Shuk-wa (2011). Negotiating Religion in Modern China: State and Common People in Guangzhou, 1900-1937. Hong Kong: Chinese University Press.

Rankin, Mary Backus (2002). "Nationalistic Contestation and Mobilization Politics: Practice and Rhetoric of Railway-Rights Recovery at the End of the Qing." Modern China 28, pp. 315-61.

Reilly, James (2006). "China's History Activism and Sino-Japanese Relations." China: An International Journal 4, pp. 189-216.

Riegel, Klaus Georg (1999). "Transplanting the Political Religion of Marxism-Leninism to China: The Case of the Sun Yatsen University in Moscow (1925-1930).” In: Karl-Heinz Pohl (ed.), Chinese Thought in a Global Context: A Dialogue between Chinese and Western Philosophical Approaches. Leiden: Brill, pp. 327-58.

Riegel, Klaus Georg (2008). "Marxism-Leninism as political religion.” In: Hans Maier and Michael Schäfer (eds.), Totalitarianism and political religions. Vol. 2: Concepts for the comparison of political dictatorships. London: Routledge, pp. 61-112.

Roy, Srila (2012). Remembering Revolution. Gender, Violence, and Subjectivity in India's Naxalbari Movement. New Delhi: Oxford University Press.

Rudolph, Jörg-Meinhard (1989). "Die Faszination der zehn chaotischen Jahre: Von der Anziehungskraft der Kulturrevolution." Orientierungen 1989:1, pp. 95-120.

Ryklin, Michail (2008). Kommunismus als Religion: Die Intellektuellen und die Oktoberrevolution, trans. Dirk and Elena Uffelmann. Frankfurt am Main: Verlag der Weltreligionen.

Schiffrin, Harold Z. (1980). Sun Yat-sen: Reluctant Revolutionary. Boston, MA: Little, Brown and Company.

Schrift, Melissa (2001). Biography of a Chairman Mao Badge: The Creation and Mass Consumption of a Personality Cult. New Brunswick, NJ: Rutgers University Press.

Schwartz, Benjamin (1964). In Search of Wealth and Power: Yan Fu and the West. Cambridge, MA: Harvard University Press.

Sheng Yueh (1971). The Sun Yatsen University in Moscow: A Personal Account. Lawrence, KN: Center for Chinese Studies, University of Kansas.

Singh, Prakash (1995). The Naxalite Movement in India. New Delhi: Rupa.

Song Qiang 宋強 et al. (1996). Zhongguo keyi shuo bu 中國可以說不 [China can say no]. $5^{\text {th }}$ edition Hong Kong: Mingbao Chubanshe.

Sun Zhongshan [Yatsen] 孙中山 (2000). Sanminzhuyi 三民主义 [The Three People's Principles]. Changsha: Yuelu Shushe (first published in 1924).

Tomba, Luigi (2009). "Of Quality, Harmony, and Community: The Middle Class in Urban China." positions: east asia cultures critique 17, pp. 592-16.

van de Ven, Hans (1991). From Friend to Comrade. The Founding of the Chinese Communist Party, 1920-1927. Berkeley, CA: University of California Press.

Voegelin, Eric (2000). "The Political Religions," trans. Virginia Ann Schildhauer. The Collected Works of Eric Voegelin. Vol 5: Modernity without Restraint, ed. Manfred Hennigsen. 
Columbia, MO: University of Missouri Press, pp. 18-73 (first published in German in 1938). Wagner, Rudolf G. (1992a). "Reading the Chairman Mao Memorial Hall in Peking: The Tribulations of the Implied Pilgrim.” In: Susan Naquin and Yü Chün-fang (eds.), Pilgrims and Sacred Sites in China. Berkeley, CA: University of California Press, pp. 378-423.

Wagner, Rudolf G. (1992b). "Konfrontation im Imaginaire: Institutionelle Struktur und Modernisierung in der Volksrepublik China." In: Dietrich Harth and Jan Assmann (eds.), Revolution und Mythos, Frankfurt am Main: Fischer, pp. 313-46.

Wakeman, Frederic (2002). "Chinese Modernity." In: Dominic Sachsenmaier, Jens Riedel and Shmuel N. Eisenstadt (eds.), Reflections on Multiple Modernities: European, Chinese, and Other Interpretations. Leiden: Brill, pp. 153-64.

Wang Liping (1996). "Creating a National Symbol: The Sun Yatsen Memorial in Nanjing." Republican China 21:2, pp. 23-63.

Wang Xiaoming 王小明 (2003). “'Zhonghua Suwei’ai Gongheguo Xianfa Dagang’ zhong de zongjiao zhengce 〈中华苏维埃共和国宪法大纲〉中的宗教政策 [Religious policy in the “Constitutional Programme of the Chinese Soviet Republic].” Beijing Dangshi 北京党史 2003:2, pp. 23-26.

Wells, Audrey (2001). The Political Thought of Sun Yat-sen. Basingstoke: Palgrave Macmillan.

Wemheuer, Felix (2008). "Einleitung: Die vielen Gesichter des Maoismus und die Neue Linke nach 1968.” In: Sebastian Gehrig, Barbara Mittler and Felix Wemheuer (eds.), Kulturrevolution als Vorbild? Maoismen in deutschsprachigen Raum. Frankfurt am Main, Germany: Lang, pp. 923.

Wenner, Jann (2000). Lennon Remembers. London: Verso (first published in 1971).

Wolin, Richard (2010). Wind From the East: French Intellectuals, the Cultural Revolution, and the Legacy of the 1960s. Princeton, NJ: Princeton University Press.

Wu Xize 吳錫澤 (1942). Guofu jinianzhou 國父紀念週 [The Weekly Remembrance of the Father of the Nation]. Chongqing: Duli Chubanshe.

“Xiuzheng zongli jinianzhou 修正總理紀念週 [The revision of the Weekly Remembrance of the Premier] (4.2.1937).” Zhongyang dangwu yuekan 中央黨務月刊 102-103, pp. 94-96.

Yang, Mayfair Mei-hui (2008). "Introduction.” In: Mayfair Mei-hui Yang (ed.), Chinese Religiosities: Afflictions of Modernity and State Formation. Berkeley, CA: University of California Press 2008, 1-40.

Ye, Jianying 叶剑英 (1979). Zai qingzhu Zhonghua Renmin Gongheguo chengli sanshi zhounian dahui shang jianghua 在庆祝中华人民共和国成立三十周年大会上的讲演 [Speech at the Assembly Celebrating the Thirtieth Anniversary of the Founding of the People's Republic of China]. Beijing: Renmin Chubanshe.

Zarrow, Peter G. (2005). China in War and Revolution, 1895-1919. Abingdon: Routledge.

Zarrow, Peter G. (2012). After Empire: The Conceptual Transformation of the Chinese State. Stanford, CA: Stanford University Press 2012. 
Zha Shijie 査時傑 (1993). “Min chu de zheng jiao guanxi. Jian lun jindai Zhongguo zheng jiao guanxi san moshi 民初的政教關係. 兼論近代中國政教關係三模式 [The relationship between politics and religion in early Republican China. A discussion of three models of the relationship between politics and religion].” In: Zha Shijie, Minguo Jidujiao shi lunwenji 民 國基督教史論文集 [A collection of essays on Republican Christianity]. Taibei: Yuzhouguang, pp. 355-94.

Zhang, Wei-wei (1996). Ideology and Economic Reform Under Deng Xiaoping, 1978-1993. London: Kegan Paul International.

Zhongguo Guomindang Zhejiang Sheng Dangwu Zhidao Weiyuanhui Xunlianbu 中國國民黨浙江省 黨務指導委員會訓練部 (1929). Zongli jinianzhou xiangjie 總理紀念週詳解. [A detailed explanation of the Weekly Remembrance of the Premier]. N.p.: Zhongguo Guomindang Zhejiang Sheng Dangwu Zhidao Weiyuanhui Xunlianbu.

Zhonghua Minguo fagui daquan 中華民國法規大全 [The complete laws of the Republic of China] (1936). Vol. 4. Shanghai: Shangwu Yinshuguan.

Zhuang Feng 庄丰 (2013). 习近平借毛泽东手法推进改革和民主化 [Xi Jinping borrows Mao's methods to promote reform and democratization], < http://boxun.com/news/gb/pubvp/2013/10/201310132002.shtml\#.UoNXa40hfNY> (accessed 13 November 2013).

Zongli danchen jinian biaoyu 總理誕辰紀念標語 [Slogans for the memory of the Premier's birthday] (1928). Jiangsu sheng zhengfu gongbao 江蘇省政府公報 59 (12 November 1928). 